\title{
What controls the isotopic composition of Greenland surface snow?
}

\author{
H. C. Steen-Larsen ${ }^{1,2,3}$, V. Masson-Delmotte ${ }^{1}$, M. Hirabayashi ${ }^{4}$, R. Winkler ${ }^{1}$, K. Satow ${ }^{4}$, F. Prié ${ }^{1}$, N. Bayou ${ }^{2}$, E. Brun ${ }^{5}$, \\ K. M. Cuffey ${ }^{6}$, D. Dahl-Jensen ${ }^{3}$, M. Dumont ${ }^{7}$, M. Guillevic ${ }^{1,3}$, S. Kipfstuhl ${ }^{8}$, A. Landais ${ }^{1}$, T. Popp ${ }^{3}$, C. Risi ${ }^{9}$, \\ K. Steffen ${ }^{2,10}$, B. Stenni ${ }^{11}$, and A. E. Sveinbjörnsdottír ${ }^{12}$ \\ ${ }^{1}$ Laboratoire des Sciences du Climat et de l'Environnement, UMR8212, CEA-CNRS-UVSQ/IPSL, Gif-sur-Yvette, France \\ ${ }^{2}$ Cooperative Institute for Research in Environmental Sciences, University of Colorado, Boulder, USA \\ ${ }^{3}$ Centre for Ice and Climate, Niels Bohr Institute, University of Copenhagen, Copenhagen, Denmark \\ ${ }^{4}$ National Institute of Polar Research, Tokyo, Japan \\ ${ }^{5}$ Meteo-France - CNRS, CNRM-GAME UMR 3589, GMGEC, Toulouse, France \\ ${ }^{6}$ Department of Geography, Center for Atmospheric Sciences, 507 McCone Hall, \\ University of California, Berkeley, CA 94720-4740, USA \\ ${ }^{7}$ Meteo-France - CNRS, CNRM-GAME UMR 3589, CEN, Grenoble, France \\ ${ }^{8}$ Alfred Wegener Institute for Polar and Marine Research, Bremerhaven, Germany \\ ${ }^{9}$ Laboratoire de Météorologie Dynamique, Jussieu, Paris, France \\ ${ }^{10}$ ETH, Swiss Federal Institute of Technology, Zurich, Switzerland \\ ${ }^{11}$ Department of Geological, Environmental and Marine Sciences, University of Trieste, Trieste, Italy \\ ${ }^{12}$ Institute of Earth Sciences, University of Iceland, Reykjavik, Iceland
}

Correspondence to: H. C. Steen-Larsen (hanschr@gfy.ku.dk)

Received: 6 October 2013 - Published in Clim. Past Discuss.: 29 October 2013

Revised: 28 December 2013 - Accepted: 6 January 2014 - Published: 20 February 2014

\begin{abstract}
Water stable isotopes in Greenland ice core data provide key paleoclimatic information, and have been compared with precipitation isotopic composition simulated by isotopically enabled atmospheric models. However, postdepositional processes linked with snow metamorphism remain poorly documented. For this purpose, monitoring of the isotopic composition $\left(\delta^{18} \mathrm{O}, \delta \mathrm{D}\right)$ of near-surface water vapor, precipitation and samples of the top $(0.5 \mathrm{~cm})$ snow surface has been conducted during two summers (2011-2012) at NEEM, NW Greenland. The samples also include a subset of ${ }^{17} \mathrm{O}$-excess measurements over 4 days, and the measurements span the 2012 Greenland heat wave. Our observations are consistent with calculations assuming isotopic equilibrium between surface snow and water vapor. We observe a strong correlation between near-surface vapor $\delta^{18} \mathrm{O}$ and air temperature $\left(0.85 \pm 0.11 \%{ }^{\circ} \mathrm{C}^{-1}(R=0.76)\right.$ for 2012$)$. The correlation with air temperature is not observed in precipitation data or surface snow data. Deuterium excess (d-excess) is strongly anti-correlated with $\delta^{18} \mathrm{O}$ with a stronger slope for vapor than for precipitation and snow surface data. During nine 1-5-day periods between precipitation events, our data
\end{abstract}

demonstrate parallel changes of $\delta^{18} \mathrm{O}$ and d-excess in surface snow and near-surface vapor. The changes in $\delta^{18} \mathrm{O}$ of the vapor are similar or larger than those of the snow $\delta^{18} \mathrm{O}$. It is estimated using the CROCUS snow model that 6 to $20 \%$ of the surface snow mass is exchanged with the atmosphere. In our data, the sign of surface snow isotopic changes is not related to the sign or magnitude of sublimation or deposition. Comparisons with atmospheric models show that day-to-day variations in near-surface vapor isotopic composition are driven by synoptic variations and changes in air mass trajectories and distillation histories. We suggest that, in between precipitation events, changes in the surface snow isotopic composition are driven by these changes in near-surface vapor isotopic composition. This is consistent with an estimated $60 \%$ mass turnover of surface snow per day driven by snow recrystallization processes under NEEM summer surface snow temperature gradients. Our findings have implications for ice core data interpretation and model-data comparisons, and call for further process studies. 


\section{Introduction}

Ice cores drilled in central Greenland, with limited summer melt, provide direct archives of past precipitation. Water stable isotope $\left(\delta^{18} \mathrm{O}\right.$ and/or $\left.\delta \mathrm{D}\right)$ measurements have been conducted along numerous shallow and deep ice cores in order to characterize past Greenland climate variability, offering seasonal records during the past millennia (Vinther et al., 2010; Ortega et al., 2014) and recently extending back to the last interglacial period (NEEM Community members, 2013).

The processes controlling water stable isotopes in midto high-latitude vapor and precipitation are, based on modern data and modeling, relatively well understood. Theoretical calculations of Rayleigh distillation show an expected $\delta^{18} \mathrm{O}$-condensation temperature slope for Greenland precipitation of $0.96 \%{ }^{\circ} \mathrm{C}^{-1}$ (Johnsen et al., 2001), coherent with the modern spatial gradient of $0.8 \% 0^{\circ} \mathrm{C}^{-1}$ of near-surface air temperature established from coastal precipitation data together with shallow ice core data (Sjolte et al., 2011). This isotope-temperature relationship (isotope thermometer) (Johnsen et al., 2001) has been central to the use of ice core water isotope records to reconstruct past Greenland climate variations. However, the comparison of water stable isotope measurements with past temperatures inferred either from the inversion of borehole temperature data (DahlJensen et al., 1998) or from the fingerprint of firn air fractionation in ice core air $\delta^{15} \mathrm{~N}$ has revealed that (i) for a given site, the isotope-temperature relationship varies through time (e.g., Guillevic et al., 2013; Landais et al., 2004; Kindler et al., 2013; Severinghaus and Brook, 1999), and (ii) for a given stadial-interstadial event, the isotope-temperature relationship varies between sites (Guillevic et al., 2013). The reported temporal isotope-temperature relationships vary between 0.3 and $0.6 \% 0^{\circ} \mathrm{C}^{-1}$.

Differences in the estimated isotope-surface-temperature relationship have been suggested to arise from (i) precipitation intermittency and the covariance between precipitation and temperature (Persson et al., 2011), (ii) changes in relationships between surface and condensation temperature linked with changes in boundary layer dynamics, and (iii) changes in moisture sources and distillation along air mass trajectories (Masson-Delmotte et al., 2005b). Simulations of water stable isotopes within regional or general circulation atmospheric models (GCM) have been used to explore the drivers of changes in isotope-temperature relationships, and evaluate models against ice core data. Such studies have confirmed the importance of precipitation seasonality for glacial-interglacial changes and highlighted the role of changes in atmospheric circulation and moisture sources (Cuffey and Steig, 1998; Jouzel et al., 1997; Krinner et al., 1997).

Second-order parameters such as the deuterium excess (dexcess; $\mathrm{d}$-excess $=\delta \mathrm{D}-8 \times \delta^{18} \mathrm{O}$ ) and more recently the ${ }^{17} \mathrm{O}$ excess are expected, based on modeling, to preserve the signature of the moisture source. The reason for this is the iso- topic composition of source moisture being controlled by kinetic effects at evaporation related to wind speed, sea surface temperature and relative humidity (for d-excess) or relative humidity (for ${ }^{17} \mathrm{O}$-excess) (Merlivat and Jouzel, 1979; Landais et al., 2012; Johnsen et al., 1989). Measurements of d-excess in Greenland ice cores have therefore been used to infer present and past evaporation conditions and locate the main moisture sources (Johnsen et al., 1989; MassonDelmotte et al., 2005b; Steen-Larsen et al., 2011). A few measurements of ${ }^{17} \mathrm{O}$-excess conducted at the seasonal scale show a seasonal cycle in anti-correlation with respect to Greenland temperature and $\delta^{18} \mathrm{O}$ (Landais et al., 2012). On stadial-interstadial timescales, existing ice core records have revealed an anti-correlation of d-excess with $\delta^{18} \mathrm{O}$, reflecting the impact of changes in cloud condensation temperature on (i) the ratio of equilibrium fractionation for $\delta \mathrm{D}$ and $\delta^{18} \mathrm{O}$ (Merlivat and Nief, 1967; Ellehoj et al., 2013) and (ii) kinetic fractionation on ice crystals (Jouzel and Merlivat, 1984). However, ice cores have also depicted specific d-excess signals spanning both present and past decadal to millennial and orbital timescales, interpreted as reflecting changes in moisture source conditions (Steffensen et al., 2008; MassonDelmotte et al., 2005a; Steen-Larsen et al., 2011). It is, however, difficult to simulate the observed Greenland ice core d-excess shifts for glacial-interglacial transitions (Werner et al., 2001; Risi et al., 2010).

The interpretation of the ice core data and the comparison with atmospheric model results implicitly rely on the assumption that the snowfall precipitation signal is perfectly preserved in the snow-ice matrix. However, post-deposition processes associated with wind scouring and firn isotopic diffusion are known to introduce a "post-deposition noise" in the surface snow. Comparisons of isotopic records obtained from nearby shallow ice cores have allowed for estimation of a "signal-to-noise" ratio with respect to a common "climate" signal (Fisher and Koerner, 1994, 1988; White et al., 1997; Steen-Larsen et al., 2011). Diffusion lengths of typically 7 $10 \mathrm{~cm}$ have been diagnosed in Greenland ice cores based on the loss of magnitude of seasonal cycles in shallow ice cores (Johnsen et al., 2000), and statistical methods have been used to "backdiffuse" ice core signals for the purpose of identifying seasonal cycles for dating ice cores or for the correction of loss of amplitude for winter and summer water stable isotope signals (Johnsen, 1977). In parallel, numerical snow models have been developed in order to represent the surface snow metamorphism, a process associated with vapor-snow mass exchanges in the upper centimeters of the firn. Snow metamorphism affects changes in grain size, surface albedo, and more generally the surface snow energy budget and mass balance (Vionnet et al., 2012; Brun et al., 2011). Snow models are growingly incorporated in atmospheric-land-surface models or used for the coupling between atmospheric and ice sheet models (Rae et al., 2012), but none of them is yet equipped with the explicit modeling of water stable isotopes. 
The motivation for our study is to investigate the impacts of post-deposition processes on (i) the isotope-temperature relationships, (ii) the d-excess vs. $\delta^{18} \mathrm{O}$ relationships and (iii) the surface snow isotopic composition in between precipitation events.

For this purpose, a surface-water-isotope-monitoring program has been established at the NEEM site, NW Greenland, with the goal of improving the interpretation of the NEEM deep ice core through a better understanding of the processes controlling the water isotopic composition measured in the ice core record at the event scale. In summer 2008, this program combined event and sub-event precipitation sampling for water stable isotope analysis, together with shallow ice core data, and water vapor monitoring using cryogenic trapping (Steen-Larsen et al., 2011). These first measurements showed parallel isotopic variations between vapor and snowfall. The near-surface water vapor isotopic composition was found to predominantly be close to isotopic equilibrium with surface snow (Steen-Larsen et al., 2011). The resolution of water vapor isotope observations was subsequently strongly improved thanks to continuous, in situ measurements using cavity ring-down spectrometers (CRDS) during summer 2010 (Steen-Larsen et al., 2013). The day-to-day variability of the near-surface atmospheric water vapor $\delta^{18} \mathrm{O}$ was in good agreement with the results from an atmospheric general circulation model, LMDZiso, nudged to atmospheric analyses. While the model did not capture the magnitude of vapor d-excess variations observed at NEEM, it showed that high dexcess events coincided with inflows of moisture originating from the Arctic (north of $70^{\circ} \mathrm{N}$ ). This finding demonstrated that large-scale atmospheric circulation changes drive dayto-day variations of NEEM near-surface water vapor. During clear-sky days, CRDS measurements conducted at heights from 1 to $13 \mathrm{~m}$ showed a strong diurnal variability in humidity and $\delta^{18} \mathrm{O}$, interpreted to reflect the fact that the snow surface acts as a moisture source (sink) during the warming (cooling) phase.

Altogether these preliminary findings have qualitatively evidenced interactions between the atmospheric water vapor and the snow surface, which has motivated further observations. Here, we report new data acquired at NEEM in summer 2011 and spring-summer 2012, which include a systematic monitoring of surface snow and water vapor, precipitation (only for 2011), and the first ${ }^{17} \mathrm{O}$-excess measurements simultaneously conducted during 4 days on water vapor and surface snow. The CROCUS snow model (Vionnet et al., 2012) has been adapted to the NEEM site and used to calculate the snow-air net mass exchange.

This manuscript is organized in the following way. Section 2 describes the NEEM site, sampling strategy and analytical methods, as well as the set up for the CROCUS model and the basis for vapor-surface snow equilibrium calculations. Section 3 describes the results of the new isotopic composition measurements and reports the $\delta^{18} \mathrm{O}$-temperature and $\mathrm{d}$-excess- $-\delta^{18} \mathrm{O}$ relationships, as well as the ${ }^{17} \mathrm{O}$-excess results. Section 4 is finally devoted to the discussion of our results and the comparison with CROCUS calculations, in order to qualitatively understand the processes controlling the isotopic composition of surface snow.

\section{Methods}

\subsection{NEEM site description}

The sampling and measurements were carried out as part of the international deep drilling program conducted at NEEM, NW Greenland $\left(77.45^{\circ} \mathrm{N}, 51.05^{\circ} \mathrm{W} ; 2484\right.$ ma.s.1.), from 2007 to 2012, providing climatic and glaciological information back to the last interglacial period (NEEM Community members, 2013; Steen-Larsen et al., 2011). An automatic weather station (AWS) was installed at the NEEM site in 2006 to supply meteorological observations. Air temperature and relative humidity (post-corrected with respect to ice) were measured using a Campbell Scientific HMP45C $\left( \pm 0.1{ }^{\circ} \mathrm{C}\right.$ and $\pm 5 \%<90 \% \mathrm{RH}$ and $\left.\pm 10 \%>90 \% \mathrm{RH}\right)$, wind direction and speed using an RM Young propellertype vane $\left( \pm 5^{\circ}\right.$ and $\left.\pm 0.1 \mathrm{~ms}^{-1}\right)$, and station pressure using Vaisala PTB101B ( $\pm 0.1 \mathrm{mb})$ (Steffen and Box, 2001; Steffen et al., 1996). The estimated mean summer (JJA) temperature at NEEM is $\sim-11 \pm 5^{\circ} \mathrm{C}(1 \sigma$ based on 3-hourly observations during the summers 2006-2011; the $1 \sigma$ on the mean summer temperatures $2006-2011$ is $\sim 1^{\circ} \mathrm{C}$ ), but the summer of 2012 was found to be significantly warmer $\left(\sim-7.5^{\circ} \mathrm{C}\right)$ than average. The annual mean accumulation rate from 1964 to 2005 is estimated to $20 \mathrm{~cm} \mathrm{a}^{-1}$ (water equivalent), with a large part (between a factor of 2.5 and 4.5 ) of precipitation occurring in JJA compared to DJF (Steen-Larsen et al., 2011). During the field campaigns of 2009-2011, a thermistor string was installed in the top snowpack between the surface and two meters depth. Extra thermistors were installed in the top snow layer throughout the season. The resistances of the thermistors were recorded using a Pico Technology 24 bit data logger. Occurrence of precipitation was recorded in the daily field report managed by the field leader.

\subsection{CRDS-analyzer measurements}

A tent was installed at the edge of the clean-air sector in the southwest corner of the NEEM camp $\sim 50 \mathrm{~m}$ from the nearest building. Inside this tent we installed a temperatureregulated box able to control the temperature to within $0.2^{\circ} \mathrm{C}$. A commercial laser-based spectrometer from Picarro Inc. (product number L1102-i) was installed inside this box. The detailed sampling and post-calibration procedure is given in Steen-Larsen et al. (2013). The inlet tubes were placed in insulation material and heated to above $50^{\circ} \mathrm{C}$. Bottles with holes in the bottom were placed at the beginning of the inlet to prevent snow from getting inside the tubes. The inlet tubes consisted of 0.25 in. outer diameter copper tubes. Two pumps were installed to increase the flow speed 
in the inlet tubes, thereby minimizing the resident time of the air inside the tubes. The flow speed of the tube being sampled was $\sim 5 \mathrm{~L} \mathrm{~min}^{-1}$, while the flow speed through each of the tubes not being sampled was $\sim 2 \mathrm{~L} \mathrm{~min}^{-1}$. To correct for the humidity dependence on the measured isotope signal, a humidity-isotope response curve was calibrated in the beginning of each measurement campaign according to the description in Steen-Larsen et al. (2013). The isotopic measurements were converted to the VSMOW-SLAP scale by measuring standards of known isotopic composition. To correct for drifts, water vapor with a known isotopic composition was measured every $6 \mathrm{~h}$. The introduction lines were installed to sample air from five levels at $\sim 1,3,7,10$ and $13 \mathrm{~m}$ above the snow surface during the 2011 campaign and two levels at $\sim 20 \mathrm{~cm}$ and $3 \mathrm{~m}$ above the snow surface during the 2012 campaign. For the 2011 campaign, each level was measured for $15 \mathrm{~min}$, of which the first $5 \mathrm{~min}$ were discarded to rule out memory effects of the inlet tubes. For the 2012 campaign the $3 \mathrm{~m}$ level was measured continuously for $45 \mathrm{~min}$ of every hour, with the other $15 \mathrm{~min}$ used for measuring the $20 \mathrm{~cm}$ level. Values are therefore reported with an hourly resolution for the 2011 data, and 15 min resolution for 2012 data, and with similar accuracy and precision as reported by Steen-Larsen et al. (2013) (Table 1). The measurements of the drift standard with known isotopic composition used to correct the drift of the instrument are shown in the Supplement Figs. S1 and S2. We do not expect that the data gaps due to drift calibrations produce any significant effect on the analysis. When the vertical gradients of water stable isotopes were investigated in Steen-Larsen et al. (2013), it was shown that they only depict diurnal gradients, and that water vapor isotopes covary at the day-to-day scale at different heights. This was also verified for our new measurements (not shown), and here we will only describe and discuss the measurements obtained at $3 \mathrm{~m}$ height (Table 1). Note that the 2011 sampling was initiated on day 185 (5 July) (noon UTC on 1 January is day 0.5), while the 2012 sampling covers a longer time period, starting on day 141 (21 May). In both years, measurements stopped at day 216 (August) due to the closure of the summer camp. Hereafter, vapor measurements are reported as $\delta^{18} \mathrm{O}_{\mathrm{v}}$ and d-excess $\mathrm{v}_{\mathrm{v}}$.

\subsection{Precipitation and snow surface samples}

A white table with $\sim 20 \mathrm{~cm}$ high sides covering an area of $\sim 0.7 \mathrm{~m}^{2}$ made out of opaque Plexiglas was installed on the edge of the clean-air sector next to the atmospheric vapor station in order to collect precipitation. The table was installed at a height of $\sim 1.5 \mathrm{~m}$ to limit the collection of blowing snow. Precipitation was collected in 2011 on event and sub-event basis as reported in Steen-Larsen et al. (2011), leading to 41 samples (Table 1). We have discarded two outliers with very low d-excess $s_{p}$ of $\sim-10 \%$.

A designated area $(5 \times 5 \mathrm{~m})$ was marked from which the snow surface samples were collected. The snow surface sam- ples were collected from the top $\sim 0.5 \mathrm{~cm}$ of the snow surface. All samples were collected within the designated area but never from any previously sampled place. The surface snow was sampled every $12 \mathrm{~h}$ (a few (25) samples were only collected every $24 \mathrm{~h}$ in the beginning of 2012) by collecting the surface from a $15 \mathrm{~cm} \times 15 \mathrm{~cm}$ area. Altogether, 51 samples were collected in 2011, and 122 samples in 2012.

Snowfall and surface snow samples were melted in sealed plastic bags before being transferred to a vial, which was kept frozen until being measured. The precipitation and snow surface samples were measured using a Picarro Inc. liquid analyzer at the Laboratoire des Sciences du Climat et de l'Environnement (LSCE), Gif-Sur-Yvette, and the Centre for Ice and Climate (CIC), Copenhagen (see Table 1). Hereafter, precipitation measurements are reported as $\delta^{18} \mathrm{O}_{\mathrm{p}}$ and d-excess $\mathrm{p}_{\mathrm{p}}$, and surface snow measurements as $\delta^{18} \mathrm{O}_{\mathrm{s}}$ and d-excess $s$.

\section{$2.4{ }^{17} \mathrm{O}$-excess of snow surface and atmospheric water vapor}

During the period from 11 to 14 July 2011, a specific sampling was conducted to explore day-to-day variations in ${ }^{17} \mathrm{O}$ excess of snow surface and atmospheric water vapor. Using a cryogenic trapping system similar to Steen-Larsen et al. (2011), water vapor from both 1 and $10 \mathrm{~m}$ above the snow surface was collected with the aim of measuring ${ }^{17} \mathrm{O}$ excess. Vapor trapping was conducted over $6 \mathrm{~h}$, leading to two samples per level per day. Because the results are very similar at the two heights, we only report the $10 \mathrm{~m}$ data here. ${ }^{17} \mathrm{O}$-excess measurements were also conducted on the corresponding subset of surface snow samples. The ${ }^{17} \mathrm{O}$-excess of the snow surface and atmospheric water vapor samples were measured at Laboratoire des Sciences du Climat et de l'Environnement (LSCE) using the fluorination technique (Barkan and Luz, 2005; Landais et al., 2012) (Table 1). The same notation for $\delta^{18} \mathrm{O}$ and d-excess is used for ${ }^{17} \mathrm{O}$-excess to report vapor data $\left({ }^{17} \mathrm{O}\right.$-excess $\left.{ }_{\mathrm{v}}\right)$ and surface snow data $\left({ }^{17} \mathrm{O}\right.$-excess $\left.\mathrm{s}\right)$.

\subsection{Calculation of equilibrium between surface snow and water vapor isotopic composition}

In order to investigate the relationship between near-surface water vapor and snow, we use the observed air temperature (see Sect. 2.1) and vapor isotopic composition (see Sect. 2.2) (integrated $12 \mathrm{~h}$ back) to estimate the expected isotopic composition of the snow surface at equilibrium with the water vapor. The calculation is performed (i) using the fractionation coefficients for liquid water extrapolated below $0{ }^{\circ} \mathrm{C}$ (Majoube, 1971), then (ii) using the fractionation coefficients for ice (Majoube, 1970) (Merlivat and Nief, 1967) and (iii) new fractionation coefficients for ice determined by Ellehoj et al. (2013). We justify the calculations assuming liquid 
Table 1. Overview of data collected during the 2011 and 2012 field campaign.

\begin{tabular}{|c|c|c|c|c|c|c|}
\hline Sample type & Time period & $\begin{array}{l}\text { Isotopic } \\
\text { measurement type }\end{array}$ & $\begin{array}{l}\text { Number of } \\
\text { samples }\end{array}$ & $\begin{array}{l}\text { Precision and } \\
\text { accuracy }\end{array}$ & $\begin{array}{l}\text { Measurement } \\
\text { type }\end{array}$ & $\begin{array}{l}\text { Place of } \\
\text { measurement }\end{array}$ \\
\hline $\begin{array}{l}\text { Picarro water } \\
\text { vapor isotope }\end{array}$ & $\begin{array}{l}\text { Day } 185 \text { to } \\
\text { day } 216 \text { of } 2011\end{array}$ & $\begin{array}{l}\delta \mathrm{D}_{\mathrm{v}}, \delta^{18} \mathrm{O}_{\mathrm{v}} \\
\text { continuously from } 3 \mathrm{~m} \\
\text { above snow surface interrupted } \\
\text { by calibration } 30 \text { min every } 6 \mathrm{~h}\end{array}$ & $\begin{array}{l}\sim \text { hourly } \\
\text { resolution }\end{array}$ & $\begin{array}{l}\delta^{18} \mathrm{O}_{\mathrm{v}}=0.23 \% \\
\delta \mathrm{D}_{\mathrm{v}}=1.4 \% o \\
(\text { Steen-Larsen } \\
\text { et al., 2013) }\end{array}$ & $\begin{array}{l}\text { Picarro CRDS } \\
\text { analyzer }\end{array}$ & NEEM \\
\hline $\begin{array}{l}\text { Picarro water } \\
\text { vapor isotope }\end{array}$ & $\begin{array}{l}\text { Day } 141 \text { to } \\
\text { day } 216 \text { of } 2012\end{array}$ & $\begin{array}{l}\delta \mathrm{D}_{\mathrm{v}}, \delta^{18} \mathrm{O}_{\mathrm{v}} \\
\text { continuously from } 3 \mathrm{~m} \\
\text { above snow surface interrupted by } \\
\text { calibration } 30 \text { min every } 6 \mathrm{~h}\end{array}$ & $\begin{array}{l}\sim 15 \min \\
\text { resolution }\end{array}$ & $\begin{array}{l}\delta^{18} \mathrm{O}_{\mathrm{v}}=0.23 \% \\
\delta \mathrm{D}_{\mathrm{v}}=1.4 \% 0 \\
(\text { Steen-Larsen } \\
\text { et al., 2013) }\end{array}$ & $\begin{array}{l}\text { Picarro CRDS } \\
\text { analyzer }\end{array}$ & NEEM \\
\hline $\begin{array}{l}\text { Cryogenic } \\
\text { collected } \\
\text { vapor }\end{array}$ & $\begin{array}{l}\text { Day } 191 \text { to } \\
194 \text { of } 2012\end{array}$ & $\begin{array}{l}{ }^{17} \mathrm{O} \text {-excess } \\
\text { from } 6 \mathrm{~h} \text { trapping of } \\
10 \mathrm{~m} \text { height vapor } \\
\text { (2 samples per day) }\end{array}$ & 7 samples & $\begin{array}{l}6 \text { ppm } \\
\text { (Landais et al., 2012) }\end{array}$ & $\begin{array}{l}\text { IRMS using } \\
\text { a flourination } \\
\text { line }\end{array}$ & LSCE \\
\hline $\begin{array}{l}\text { Precipitation } \\
\text { samples }\end{array}$ & $\begin{array}{l}\text { Day } 189 \text { to } \\
\text { day } 210 \text { of } 2011\end{array}$ & $\begin{array}{l}\delta \mathrm{D}_{\mathrm{p}}, \delta^{18} \mathrm{O}_{\mathrm{p}} \\
\text { Sub-event resolution }\end{array}$ & 41 samples & $\begin{array}{l}\delta^{18} \mathrm{O}_{\mathrm{p}}=0.1 \% \circ \\
\delta \mathrm{D}_{\mathrm{p}}=1.0 \% \circ\end{array}$ & $\begin{array}{l}\text { Picarro CRDS } \\
\text { analyzer }\end{array}$ & LSCE \\
\hline $\begin{array}{l}\text { Snow surface } \\
\text { samples }\end{array}$ & $\begin{array}{l}\text { Day } 188 \text { to } \\
\text { day } 215 \text { of } 2011\end{array}$ & $\begin{array}{l}\delta \mathrm{D}_{\mathrm{s}}, \delta^{18} \mathrm{O}_{\mathrm{s}} \\
\text { every } 12 \mathrm{~h}\end{array}$ & 51 samples & $\begin{array}{l}\delta^{18} \mathrm{O}_{\mathrm{s}}=0.1 \% 0 \\
\delta \mathrm{D}_{\mathrm{s}}=1.0 \% 0\end{array}$ & $\begin{array}{l}\text { Picarro CRDS } \\
\text { analyzer }\end{array}$ & LSCE \\
\hline $\begin{array}{l}\text { Snow surface } \\
\text { samples }\end{array}$ & $\begin{array}{l}\text { Day } 191 \text { to } \\
\text { day } 194 \text { of } 2011\end{array}$ & $\begin{array}{l}{ }^{17} \mathrm{O} \text {-excess } \\
\text { every } 12 \mathrm{~h}\end{array}$ & 7 samples & $6 \mathrm{ppm}$ & $\begin{array}{l}\text { IRMS using } \\
\text { a flourination line }\end{array}$ & LSCE \\
\hline $\begin{array}{l}\text { Snow surface } \\
\text { samples }\end{array}$ & $\begin{array}{l}\text { Day } 143 \text { to } \\
\text { day } 214 \text { of } 2012\end{array}$ & $\begin{array}{l}\delta \mathrm{D}_{\mathrm{s}}, \delta^{18} \mathrm{O}_{\mathrm{s}} \\
\text { every } 24 \mathrm{~h}(\text { day } 143-165) \\
\text { every } 12 \mathrm{~h}(\text { day } 166-214)\end{array}$ & 122 samples & $\begin{array}{l}\delta^{18} \mathrm{O}_{\mathrm{s}}=0.1 \% \circ \\
\delta \mathrm{D}_{\mathrm{s}}=1.0 \% \circ\end{array}$ & $\begin{array}{l}\text { Picarro CRDS } \\
\text { analyzer }\end{array}$ & $\mathrm{CIC}$ \\
\hline
\end{tabular}

water by the fact that the summer temperatures at NEEM are close to $0^{\circ} \mathrm{C}$ (Fig. 1). Results are reported in Sect. 3.8.

\subsection{LMDZiso}

The measurements are compared with simulations using the atmospheric general circulation model LMDZ (Hourdin et al., 2006). It is enabled with water isotopes (Risi et al., 2010) and the simulated water isotopic distribution has been validated at various timescales globally (Risi et al., 2010, 2013) and over Greenland (Steen-Larsen et al., 2011; Ortega et al., 2014). The details of isotopic implementation are given in Risi et al. (2010).

LMDZ is used here with a resolution of $2.5^{\circ}$ in latitude, $3.75^{\circ}$ in longitude and 39 vertical levels. The first atmospheric layer is $60 \mathrm{~m}$ thick. The simulated winds are nudged towards those of the ECMWF operational analyses, allowing the model to reproduce the day-to-day large-scale atmospheric conditions (Risi et al., 2010; Yoshimura et al., 2008).

Snow is represented as a single, vertically homogeneous layer. The mass fluxes into the layer are snowfall and frost (deposition) and the mass fluxes out of the layer are melt, sublimation "and model-layer overflow". Melt and sublimation are assumed not to fractionate. Frost is formed in equilibrium with the water vapor of the first atmospheric layer. "Model-layer overflow" occurs whenever the snow height exceeds a maximum capacity of $3 \mathrm{~m}$. The "model-layer overflow" is carried out in the simulation by simply removing from the calculations any part of the homogeneous snow layer that exceeds $3 \mathrm{~m}$. In practice, at NEEM, the snow layer is almost always at its maximum capacity. Therefore, the isotopic composition of the snow varies very little at the daily scale in the model, since the snow height variations through snowfall or through frost are several orders of magnitudes smaller than the total snow layer height.

\subsection{CROCUS}

We run the detailed snowpack model CROCUS (Vionnet et al., 2012) to drive the energy and mass fluxes between the atmosphere and the snow surface as well as the snow grain metamorphism. The meteorological forcing required by the model was extracted from ERA-Interim (Dee et al., 2011) and projected onto NEEM as in Brun et al. (2013). The precipitation rate was multiplied by a factor of 2 in order to match the annual accumulation record at NEEM. This adjustment does not significantly change the simulated heat and vapor surface fluxes. ERA-Interim air temperature and humidity were compared with observations from the GCNET (Greenland Climate Network) station at NEEM (Steffen and Box, 2001; Steen-Larsen et al., 2011). A strong linear correlation of ERA-Interim temperature vs. observations is found with $<1^{\circ} \mathrm{C}$ deviation to the $1: 1$ line for the range -20 to $0^{\circ} \mathrm{C}(R=0.95)$. Similar strong linear correlation between ERA-Interim air humidity and observation is found with $<100$ ppmv deviation to the $1: 1$ lines for the range 

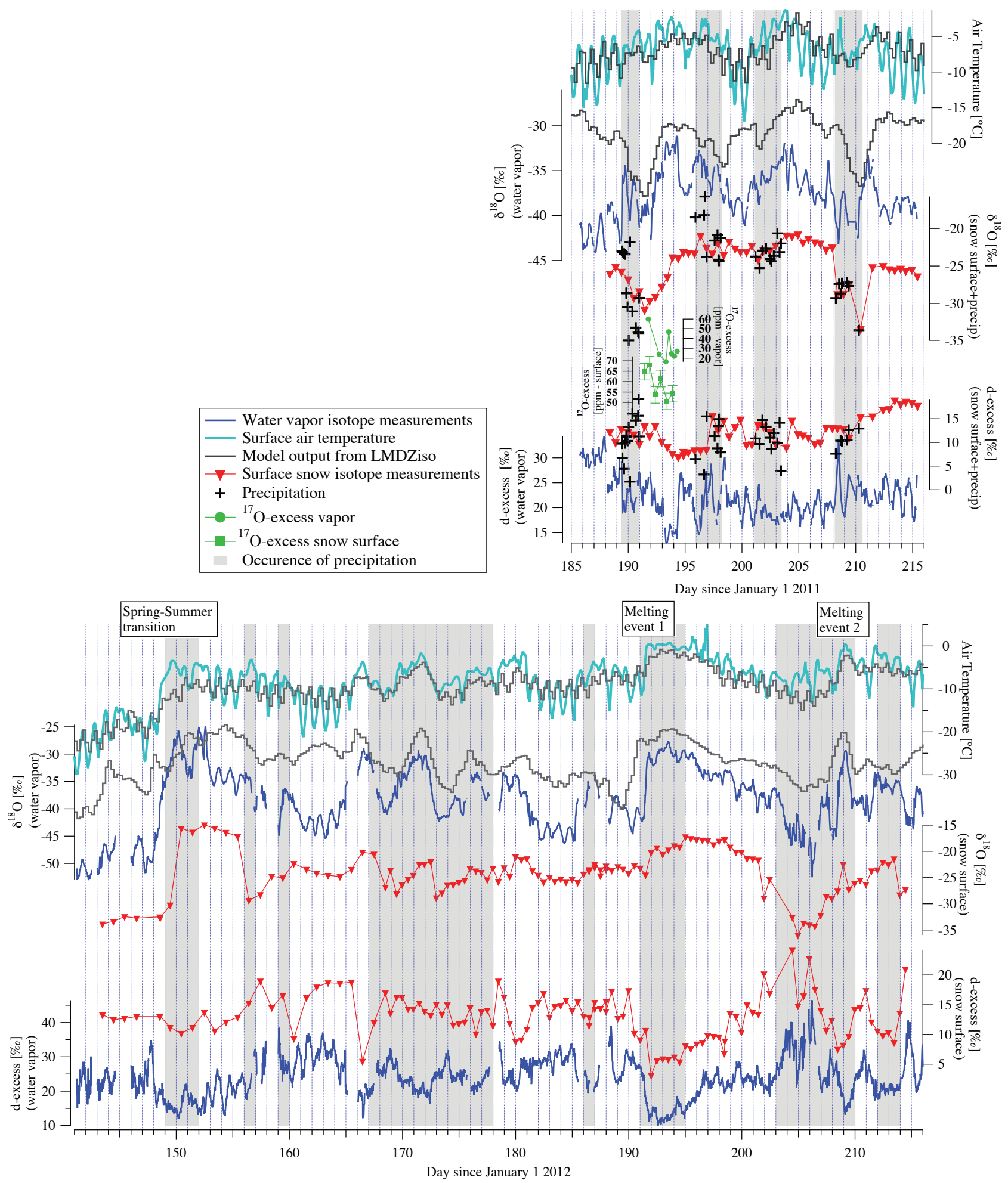

Fig. 1. The observed water vapor isotope signal during the 2011 (top panel) and 2012 (bottom panel) field season at NEEM (shown in blue) together with the concomitant variability in the surface snow isotopes (show in red). Air temperature from local GC-Net station shown in cyan. Model outputs from LMDZiso shown with solid dark-gray line. Occurrence of precipitation indicated by vertical gray columns. Precipitation samples collected in 2011 on sub-event shown with black crosses in top panel. 
2000 to $8000 \mathrm{ppmv}(R=0.94)$. An evaluation of the snow surface temperature simulated with CROCUS was also carried out. As part of the snow surface monitoring program we installed thermistor probes from the surface and to a depth of $\sim 2 \mathrm{~m}$. However due to solar heating of the top thermistors and uncertainty in vertical position we use surface temperature estimates from MODIS MOD11_L2 from TERRA and MYD11_L2 from AQUA (Wan, 2009) for clear-sky days and find a very good agreement to surface temperature estimates from CROCUS (see Fig. S3 in Supplement). This performance makes it possible to reliably calculate the vapor fluxes exchanged between the atmosphere and the surface snow layers.

\section{Results}

\subsection{NEEM climate during summer 2011 and spring-summer 2012}

The mean air temperature during summer 2011 (day 185216) and spring-summer 2012 (day $140-216$ ) is $-6.9^{\circ} \mathrm{C}$ and $-6.8^{\circ} \mathrm{C}$, respectively (see Fig. 1). Diurnal cycles have a magnitude of $\sim 5-10^{\circ} \mathrm{C}$ during clear-sky days, but with a reduced magnitude during precipitation events, caused by the clouds leading to a increase in downwelling longwave radiation. Daily averaged temperatures (Fig. 1) show day-to-day variations associated with changes in the largescale atmospheric circulation, well captured by the LMDZiso nudged simulation (Fig. 1). The summer near-surface air temperatures reached levels close to or slightly above $0{ }^{\circ} \mathrm{C}$ for several episodes during both 2011 and 2012. Particularly remarkable are two events in 2012 around day 191-196 (1015 July) and around day 209 (28 July), during which melting of the surface layer was observed (indicated in Fig. 1). As reported in Steen-Larsen et al. (2011) based on satellite microwave data, starting in 1987, melt has previously (since 1987) occurred in summer 2005 (24 and 25 July 2005). This 2005 two-day event was likely caused by the same cyclonic event rather than from two separate events as in 2012. The 2012 measurements span the spring-summer transition around day 147-150. This transition was not recorded in the 2010 or 2011 data sets, as measurements were not initiated before the summer period had started. During the transition over these days the air temperature increased by $\sim 20-25{ }^{\circ} \mathrm{C}$ (minimum to maximum)

\subsection{Variability of $\delta^{18} \mathrm{O}_{\mathrm{v}}$ and d-excess $\mathrm{v}$ during summer 2011 and spring-summer 2012}

We describe the 2011 and 2012 vapor $\delta^{18} \mathrm{O}_{\mathrm{v}}$ and d-excess $\mathrm{v}$ data, report the mean value and range of variations (Table 2), and highlight two remarkable events recorded in spring and summer 2012.

Figure 1 shows that $\delta^{18} \mathrm{O}_{\mathrm{v}}$ varied between -44 and $-32 \%$, with an average of $\sim-37 \%$ o during July to early
August 2011. The mid-May to early August 2012 data vary between -53 and $-25 \%$, with an average of $\sim-38 \%$. Altogether, the range of variation and the mean value are representative of summer values at NEEM as reported earlier (Steen-Larsen et al., 2011, 2013), with the exception of the strongly depleted values in May 2012, which captures seasonal variations associated with major warming from spring to summer.

During days with clear-sky conditions, $\sim 4 \%$ o diurnal variations of $\delta^{18} \mathrm{O}_{\mathrm{v}}$ occur in phase with the near-surface air temperature and humidity diurnal cycle, confirming the results obtained in 2010 (Steen-Larsen et al., 2013). These diurnal cycles are not further investigated here, as we will subsequently focus on day-to-day variations.

Both in 2011 and 2012, synoptic variations (large-scale cyclonic variations) in $\delta^{18} \mathrm{O}_{\mathrm{v}}$ of typically $4-10 \%$ occur within 1 to 3 days with parallel variations in near-surface air temperatures and humidity. We note that significant variations in $\delta^{18} \mathrm{O}_{\mathrm{v}}$ occur during precipitation events (gray-shaded areas of Fig. 1) and in between precipitation events. As also shown for summer 2010 (Steen-Larsen et al., 2013), the dayto-day variability of temperature and $\delta^{18} \mathrm{O}_{\mathrm{v}}$ is well captured by LMDZiso (Fig. 1). This confirms that such changes in the $\delta^{18} \mathrm{O}_{\mathrm{v}}$ are driven by changes in large-scale circulation, since only the large-scale winds are nudged in this simulation. We do not further investigate the comparison between LMDZiso and our data, as this will be the focus of a separate multimodel-data paper currently in preparation.

Two remarkable $\delta^{18} \mathrm{O}_{\mathrm{v}}$ events are observed during the 2012 campaign. The largest event (“spring 2012 event”) with an increase of $\sim 25 \%$ occurs from day 147 to 150 , reflecting the transition from spring to summer. The fastest event ("summer 2012 event") is a sharp increase in $\delta^{18} \mathrm{O}_{\mathrm{v}}$ by $\sim 12 \%$ over $6 \mathrm{~h}$ associated with $\sim 11^{\circ} \mathrm{C}$ warming on day 191. This event reflects the advection of warm air associated with an atmospheric river (Newell and Zhu, 1994), which led to a record heat wave and melting on $98 \%$ of the surface of the Greenland Ice Sheet (Nghiem et al., 2012).

During summer 2011, d-excess $\mathrm{v}_{\mathrm{v}}$ varies between $\sim 13$ and $\sim 34 \%$, with an average of $\sim 22 \%$, while during springsummer 2012 a larger range of variations was obtained from $\sim 10$ to $\sim 46 \%$, with a similar average of $\sim 23 \%$. The range and mean value are comparable to observations from 2010 reported in Steen-Larsen et al. (2013), where a mean value of $\sim 26 \%$ o was observed together with observations of large dexcess values (> 40\%o). Data from 2010, 2011 and 2012 all show a general anti-correlation between $\delta^{18} \mathrm{O}_{\mathrm{v}}$ and d-excess $\mathrm{v}$ for synoptic events.

Based on the anomaly of the spring signal in 2012, we disregard this period when investigating $\delta^{18} \mathrm{O}$-temperature (Sect. 3.6) or d-excess- $-\delta^{18} \mathrm{O}$ (Sect. 3.7) relationships. 
Table 2. Overview of the distribution of the observed $\delta^{18} \mathrm{O}$ and d-excess together with the slope and correlation for d-excess vs. $\delta^{18} \mathrm{O}$ and $\delta^{18} \mathrm{O}$ vs. air temperature for the atmospheric water vapor, precipitation samples, and snow surface samples.

\begin{tabular}{|c|c|c|c|c|c|c|c|c|c|}
\hline Sample type & Year & $\begin{array}{l}\text { Measurement } \\
\text { type }\end{array}$ & Minimum & Maximum & Average & $\begin{array}{r}\text { Slope } \\
\text { d-excess } \\
\text { vs. } \delta^{18} \mathrm{O}\end{array}$ & $\begin{array}{r}R \\
\text { d-excess } \\
\text { vs. } \delta^{18} \mathrm{O}\end{array}$ & $\begin{array}{r}\text { Slope } \\
\delta^{18} \mathrm{O} \text { vs. Air } \\
\text { temp. }\end{array}$ & $\begin{array}{r}R \\
\delta^{18} \mathrm{O} \text { vs. } \\
\text { Air temp. }\end{array}$ \\
\hline \multirow{4}{*}{$\begin{array}{l}\text { Atmospheric } \\
\text { water vapor }\end{array}$} & 2011 & $\delta^{18} \mathrm{O}$ & -44 & -32 & -37 & -1.14 & -0.76 & 0.81 & 0.77 \\
\hline & & d-excess & 13 & 34 & 22 & & & & \\
\hline & 2012 & $\delta^{18} \mathrm{O}$ & -53 & -25 & -38 & -1.03 & -0.86 & 0.85 & 0.76 \\
\hline & & d-excess & 10 & 46 & 23 & & & & \\
\hline \multirow{2}{*}{$\begin{array}{l}\text { Precipitation } \\
\text { samples }\end{array}$} & 2011 & $\delta^{18} \mathrm{O}$ & -35 & -18 & -26 & -0.47 & -0.57 & 0.64 & 0.24 \\
\hline & & d-excess & 2 & 20 & 11 & & & & \\
\hline \multirow{4}{*}{$\begin{array}{l}\text { Snow surface } \\
\text { samples }\end{array}$} & 2011 & $\delta^{18} \mathrm{O}$ & -33 & -21 & -25 & -0.31 & -0.28 & - & 0.17 \\
\hline & & d-excess & 7 & 19 & 12 & & & & \\
\hline & 2012 & $\delta^{18} \mathrm{O}$ & -36 & -15 & -24 & -0.44 & -0.53 & 0.31 & 0.32 \\
\hline & & d-excess & 3 & 24 & 13 & & & & \\
\hline
\end{tabular}

\subsection{Variability of $\delta^{18} \mathrm{O}_{\mathrm{p}}$ and d-excess $\mathrm{p}$ during summer 2011}

The precipitation samples collected during summer 2011 cover four precipitation events (Fig. 1). The $\delta^{18} \mathrm{O}_{\mathrm{p}}$ and $\mathrm{d}$ excess $_{\mathrm{p}}$ of the samples vary respectively between $\sim-35$ and $\sim-18 \%$ with a mean value (arithmetic mean) of $\sim-26 \%$ o and between $\sim 2$ and $\sim 20 \%$ with a mean value of $\sim 11 \%$ o (Table 2). No systematic pattern of change can be observed during precipitation events regarding the trends in the isotopic composition of precipitation or vapor.

\subsection{Variability of $\delta^{18} \mathrm{O}_{\mathrm{s}}$ and d-excess $s_{\mathrm{s}}$ during summer 2011 and spring-summer 2012}

During summer 2011, $\delta^{18} \mathrm{O}_{\mathrm{s}}$ varies between $\sim-33$ and $\sim$ $-21 \%$ with an average value of $\sim-25 \%$. The range of values is smaller compared to $\delta^{18} \mathrm{O}_{\mathrm{p}}$, and the mean value is $1 \%$ more enriched than the average $\delta^{18} \mathrm{O}_{\mathrm{p}}$. A larger range of variations is observed in spring-summer 2012, with $\delta^{18} \mathrm{O}_{\mathrm{s}}$ varying between $\sim-36$ and $\sim-15 \%$ o with an average value of $-24 \%$ o (a similar value is obtained when averaging over the same data collection period in 2011).

For d-excess, the summer 2011 is characterized by values between $\sim 7$ and $\sim 19 \%$ o with a mean value of $\sim 12 \%$. The range is smaller than depicted in the precipitation data (consistent with different sampling durations), and the mean value is identical. A larger range of variations is observed in spring-summer 2012 , from $\sim 3$ and $\sim 24 \%$ with an average value of $\sim 13 \%$ o (averaging over the same period as 2011 yields a value of $\sim 12 \%$ o).

The isotopic composition of the surface snow varies during precipitation events, consistent with the magnitude of the precipitation isotopic composition changes (Fig. 1, summer 2011). While this is expected from new snow deposition, variations in the isotopic composition of the snow surface are easily observed in between precipitation events. System- atic comparisons between these evolutions of surface snow and vapor isotopic composition are conducted and discussed in Sect. 4.

\section{$3.5 \quad{ }^{17} \mathrm{O}$-excess data}

Between days 191 and 194 of 2011, larger variations (from 16 to $60 \mathrm{ppm}$ ) are recorded in ${ }^{17} \mathrm{O}$-excess ${ }_{\mathrm{v}}$ than in ${ }^{17} \mathrm{O}$ excess $_{\mathrm{s}}$ (50 to $68 \mathrm{ppm}$ ) (Table 2). This finding confirms similar results obtained from samples collected during days 224 228 of 2008 , showing a larger range of variability in vapor (10-70 ppm) compared to precipitation data (20-40 ppm) (Landais et al., 2012). These reported values are within the range observed in shallow cores at NEEM (Landais et al., 2012). We also conclude from this small data set that changes in ${ }^{17} \mathrm{O}$-excess of water vapor and surface snow occur in between precipitation events, and show qualitatively parallel trends, albeit with larger amplitude in the vapor than the snow surface.

\section{6 $\delta^{18} \mathrm{O}$-temperature relationships in vapor, precipitation and surface snow}

The summer $\delta^{18} \mathrm{O}_{\mathrm{v}}$ data exhibit a strong correlation with near-surface air temperature (Fig. 2, Table 2), with a slope of $\sim 0.81 \pm 0.13 \% 0^{\circ} \mathrm{C}^{-1}(R=0.77)$ in 2011 (from daily mean values), very similar to the slope observed in 2012 summer observations, $\sim 0.85 \pm 0.11 \% 0^{\circ} \mathrm{C}^{-1}(R=0.76)$ for 2012. When including the observations before the springsummer transition results in a slope of $\sim 0.86 \% 0^{\circ} \mathrm{C}^{-1}$.

A very low correlation is found between $\delta^{18} \mathrm{O}_{\mathrm{p}}$ and temperature, with a slope of $\sim 0.64 \pm 0.49 \% 0^{\circ} \mathrm{C}^{-1}(R=0.24)$. In order to explore the relationship between isotopic composition of surface snow and temperature, we use the mean air temperature averaged over $12 \mathrm{~h}$ prior to collection of the snow surface sample. The result does not depend on the integration time (tested over durations of 1 to $48 \mathrm{~h}$ ). No 

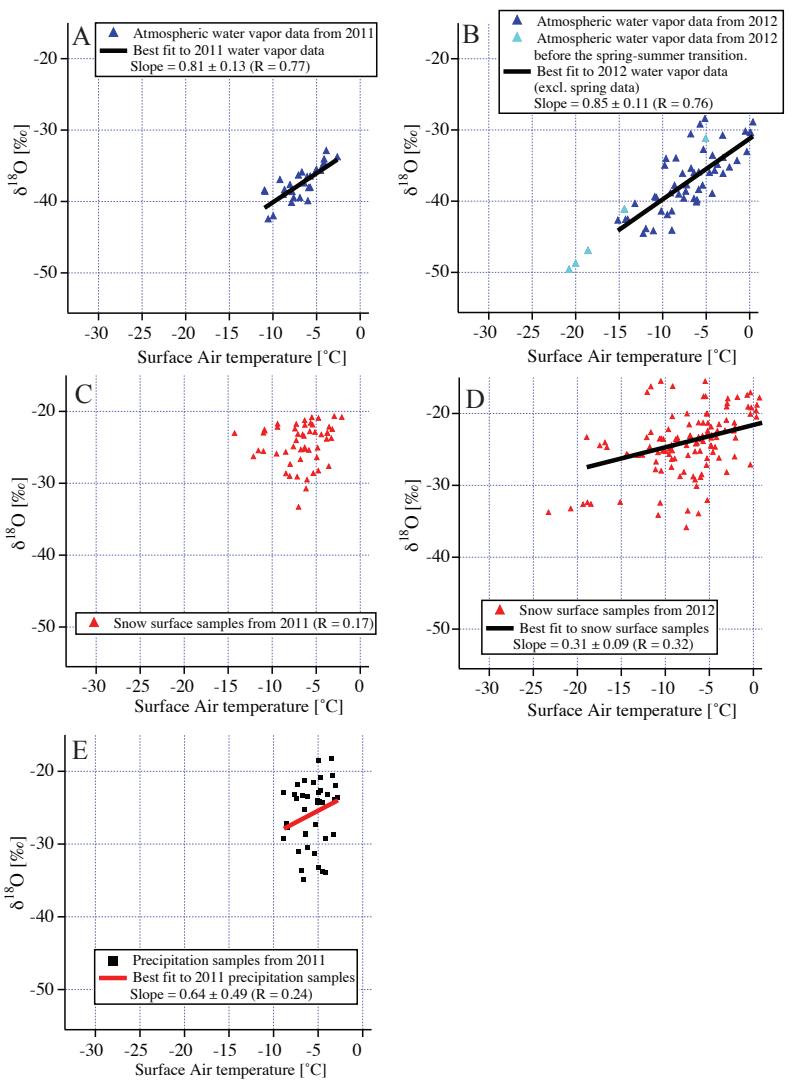

Fig. 2. The $\delta^{18} \mathrm{O}$ vs. surface air temperature for the observed mean daily water vapor isotopes (A: 2011; B: 2012), surface snow samples (C: 2011; D: 2012), and precipitation samples (E: 2011).

significant correlation is detected between $\delta^{18} \mathrm{O}_{\mathrm{s}}$ and air temperature during 2011. In summer 2012, a significant correlation is associated with a slope of $\sim 0.31 \pm 0.09 \%{ }^{\circ} \mathrm{C}^{-1}$ $(R=0.32)$ (Fig. 2, Table 2) due to the presence of surface snow samples collected before the spring-summer transition.

\section{7 d-excess- $\delta^{18} \mathrm{O}$ relationships in vapor, precipitation and surface snow in summer 2011 and 2012}

For summer vapor data (excluding the 2012 spring-summer transition), daily mean d-excess $\mathrm{v}_{\mathrm{v}}$ is anti-correlated with $\delta^{18} \mathrm{O}_{\mathrm{v}}$, with slopes of $\sim-1.16 \pm 0.14 \%$ o per permil in 2011 $(R=-0.86)$ and $\sim-1.04 \pm 0.06 \%$ o per permil in $2012(R=$ $-0.91)$ (Fig. 3). Similar slopes are obtained from hourly data. By contrast, a weaker relationship associated with a smaller slope emerges from 2011 surface snow data $(\sim-0.31 \pm$ $0.15 \%$ o per \%o, $R=-0.28$ ) as well as 2012 surface snow data $(\sim-0.44 \pm 0.07 \%$ o per permil, $R=-0.53)$. The latter is closer to the relationship obtained from precipitation data both from our 2011 data set $(\sim-0.47 \pm 0.11 \%$ o per permil, $R=-0.57$ ) and reported from 2008 precipitation data by Steen-Larsen et al., $2011(-0.43 \pm 0.14, R=-0.58)$.
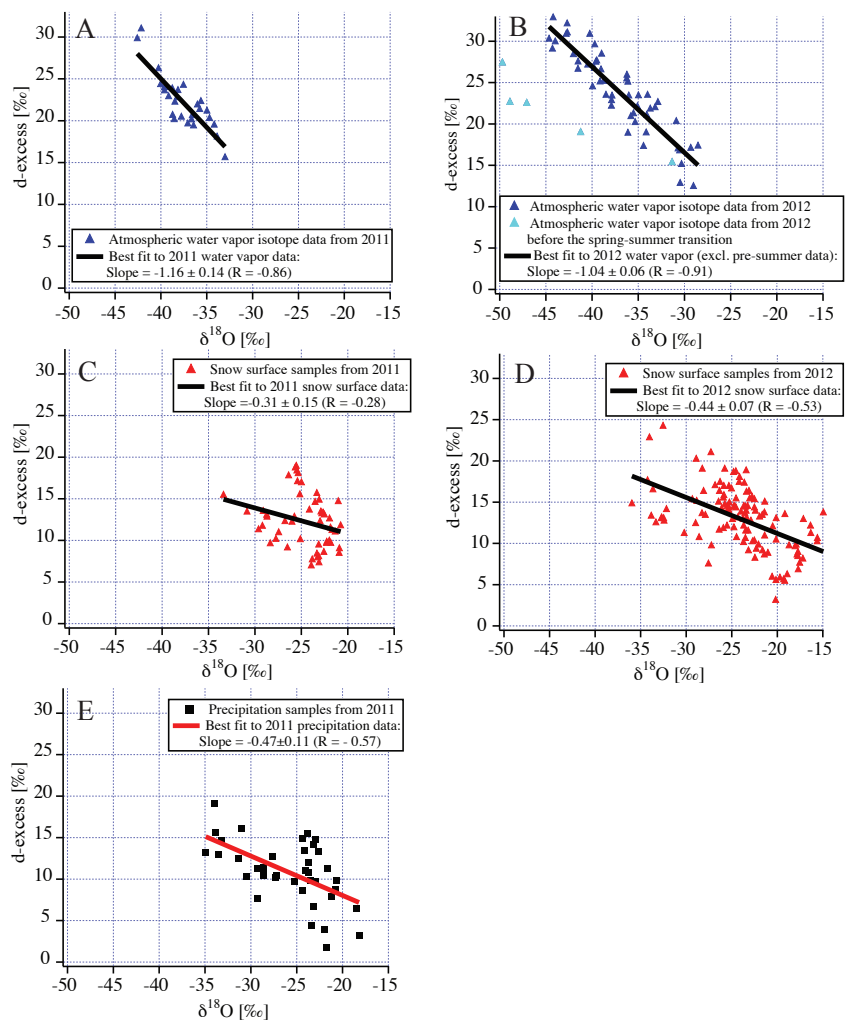

Fig. 3. The d-excess vs. $\delta^{18} \mathrm{O}$ for the observed mean daily water vapor isotopes (A: 2011; B: 2012), surface snow samples (C: 2011; D: 2012), and precipitation samples (E: 2011).

Table 3. Mean summer surface snow isotopic composition from observations and the calculation of equilibrium with surface water vapor at surface air temperature.

\begin{tabular}{|c|c|c|c|c|}
\hline Summer & $\begin{array}{l}\text { Observed } \\
\text { mean } \\
\text { values }\end{array}$ & $\begin{array}{l}\text { Equilibrium } \\
\text { with water } \\
\text { (Majoube, } \\
\text { 1971) }\end{array}$ & $\begin{array}{l}\text { Equilibrium with ice } \\
\text { (Majoube, 1970; } \\
\text { Merlivat and } \\
\text { Nief, 1967) }\end{array}$ & $\begin{array}{l}\text { Equilibrium } \\
\text { with ice } \\
\text { (Ellehoj et } \\
\text { al., 2013) }\end{array}$ \\
\hline \multicolumn{5}{|l|}{2011} \\
\hline$\delta^{18} \mathrm{O}_{\mathrm{s}}$ & -25 & $-25 \%$ & $-21 \%$ & $-22 \% 0$ \\
\hline $\begin{array}{l}\text { d-excesss: } \\
2012\end{array}$ & 12 & $16 \%$ & $1 \%$ & $10 \%$ \\
\hline$\delta^{18} \mathrm{O}_{\mathrm{s}}$ & -24 & $\sim-26 \%$ & $-22 \%$ & $-23 \%$ \\
\hline
\end{tabular}

\subsection{Comparison between measured surface snow isotopic composition and values calculated from isotopic equilibrium with near-surface water vapor}

To study the relationship between the surface snow and water vapor isotopic composition, we compare the calculated surface snow isotopic composition, using the method described in Sect. 2.7, to the observed data in Fig. 4, with the mean summer isotopic values summarized in Table 3 .

The observed $\delta^{18} \mathrm{O}_{\mathrm{s}}$ variations lie in between the theoretical calculations of a surface snow at equilibrium with 


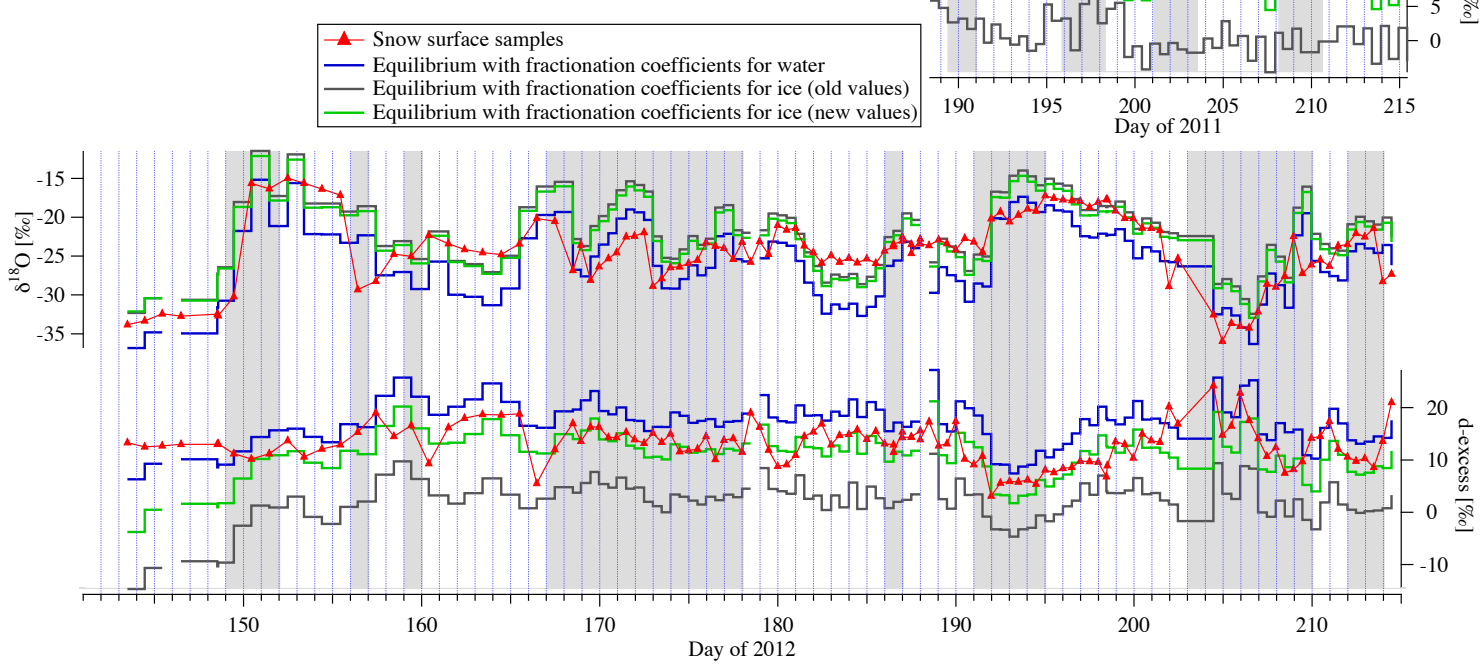

Fig. 4. $\delta^{18} \mathrm{O}$ and d-excess of the condensate calculated based on the air temperature and observed atmospheric water vapor isotopic composition under the assumptions of isotopic equilibrium. Different fractionation coefficients were used assuming liquid water (Majoube, 1971), ice (Majoube, 1970; Merlivat and Nief, 1967), and ice but with new fractionation coefficients estimated by Ellehoj et al. (2013).

vapor using liquid water and ice. During precipitation events, a better agreement is obtained using fractionation with water, while between precipitation events a better agreement is found for calculations of fractionation with ice in between precipitation events.

The observed d-excess $s_{\mathrm{s}}$ data also lie between the results obtained when using fractionation factors for liquid water and ice, but a much better fit is obtained when using the new ice fractionation coefficients (Ellehoj et al., 2013). Calculations with the old ice fractionation coefficients led to values much lower than observed.

From this comparison, the hypothesis of equilibrium between vapor and surface snow cannot be rejected. We note that equilibrium between near-surface vapor and precipitation was also suggested from $2008 \delta^{18} \mathrm{O}$, d-excess and ${ }^{17} \mathrm{O}$ excess data (Steen-Larsen et al., 2011; Landais et al., 2012).

\section{Discussion}

\subsection{Robustness of findings when comparing different years:}

1. We find similar mean temperature, $\delta^{18} \mathrm{O}$ and d-excess values in vapor and surface snow for 2011 and 2012.
2. For different years a comparable relationship is found between d-excess vs. $\delta^{18} \mathrm{O}$, and $\delta^{18} \mathrm{O}$ vs. temperature in vapor $(2008,2010,2011,2012)$, precipitation $(2008$, 2011), and surface snow (2011 and 2012).

3. We conclude that different $\delta^{18} \mathrm{O}$-temperature and dexcess- $\delta^{18} \mathrm{O}$ slopes exist for vapor and surface snow.

4. Our observations indicate that surface snow is at equilibrium with near-surface water vapor (or vice versa).

5. The good agreement between LMDZiso simulations of day-to-day variations in $\delta^{18} \mathrm{O}_{\mathrm{v}}$ indicates that water vapor isotope variations are driven by large-scale circulation features.

We will therefore subsequently assume that the same processes are at play for several summers despite different meteorological conditions. We seek to investigate what drives the observed variation of surface snow isotopic composition in between snowfall events by comparing magnitudes of change in surface snow isotopes with simultaneous change in water vapor isotope (Sect. 4.2) and investigating possible processes that can explain the observed variation (Sect. 4.3). 
Table 4. Changes in surface snow and water vapor isotopic composition in between precipitation events. The value is calculated by comparing the mean over the specific days.

\begin{tabular}{|c|c|c|c|c|c|}
\hline $\begin{array}{l}\text { Day } \\
\text { begin }\end{array}$ & $\begin{array}{l}\text { Day } \\
\text { end }\end{array}$ & $\begin{array}{l}\text { Change in } \\
\text { snow surface } \\
\delta^{18} \mathrm{O}_{\mathrm{s}}[\% \text { o }]\end{array}$ & $\begin{array}{l}\text { Change in } \\
\text { water vapor } \\
\delta^{18} \mathrm{O}_{\mathrm{V}}[\% \text { o }\end{array}$ & $\begin{array}{l}\text { Change in } \\
\text { snow surface } \\
\text { d-excess }[\% o]\end{array}$ & $\begin{array}{l}\text { Change in } \\
\text { water vapor } \\
\text { d-excess }[\% \text { [ }]\end{array}$ \\
\hline \multicolumn{6}{|l|}{2011} \\
\hline 191 & 194 & $\sim+7.0$ & $\sim+8.0$ & $\sim-6$ & $\sim-10$ \\
\hline 199 & 200 & $\sim-1.3$ & $\sim-1.3$ & - & - \\
\hline 204 & 207 & $\sim+2.4$ & $\sim+5.0$ & $\sim-5$ & - \\
\hline 211 & 214 & $\sim-0.5$ & $\sim-3.5$ & $\sim+3$ & - \\
\hline \multicolumn{6}{|l|}{2012} \\
\hline 153 & 155 & $\sim-2$ & $\sim-2$ & $\sim+2$ & $\sim+2$ \\
\hline 160 & $163 / 164$ & $\sim-4$ & $\sim-4$ & $\sim+10$ & $\sim+7$ \\
\hline $163 / 164$ & 166 & $\sim+5$ & $\sim+12$ & $\sim-13$ & $\sim-13$ \\
\hline 180 & 183 & $\sim-4$ & $\sim-8.5$ & $\sim+8$ & $\sim+7$ \\
\hline 196 & 201 & $\sim-4$ & $\sim-8$ & $\sim+7$ & $\sim+6$ \\
\hline
\end{tabular}

\subsection{Magnitude of isotopic changes in surface snow and near-surface water vapor}

We focus on changes in snow surface isotope values occurring in between precipitation events. We have (between day 191 and 194 of 2011) concomitant $\delta^{18} \mathrm{O}$, d-excess and ${ }^{17} \mathrm{O}$-excess data for one period. During this period, $\delta^{18} \mathrm{O}_{\mathrm{s}}$ increases by $\sim 7 \%$ in parallel with a $\sim 8 \%$ increase in $\delta^{18} \mathrm{O}_{\mathrm{v}}$. Similarly, d-excess $\mathrm{s}_{\mathrm{s}}$ decreases by $\sim 6 \%$, while $\mathrm{d}$ excess $_{\mathrm{V}}$ decreases by $\sim 10 \%$. Finally, ${ }^{17} \mathrm{O}$-excess excreases $_{\mathrm{S}}$ incre by $\sim 15 \mathrm{ppm}$, while ${ }^{17} \mathrm{O}$-excess $\mathrm{v}_{\mathrm{v}}$ increases by $\sim 40 \mathrm{ppm}$. During this event, the isotopic composition of the surface snow varies in parallel with that of water vapor, albeit with an attenuated magnitude.

In order to test whether this finding is valid for all periods in between precipitation, Table 3 shows a systematic investigation of the sign and magnitude of changes in $\delta^{18} \mathrm{O}_{\mathrm{s}}$, $\delta^{18} \mathrm{O}_{\mathrm{v}}, \mathrm{d}$-excess $\mathrm{s}_{\mathrm{s}}$ and d-excess $\mathrm{v}_{\mathrm{v}}$. Note that no lead or lag time could be identified for the simultaneous changes in the surface snow and water vapor isotopic composition seen in Fig. 1 and documented in Table 4, due to the time resolution of the surface snow measurements.

Table 4 demonstrates that changes in snow surface and water vapor isotopes systematically occur in the same direction, with the exception of two periods (2011, days 204-207 and 211-214) where significant changes are detected in d-excess ${ }_{\mathrm{S}}$ but not in d-excess $\mathrm{v}_{\mathrm{v}}$. Magnitudes of observed changes in $\delta^{18} \mathrm{O}_{\mathrm{s}}$ are either similar (2 situations out of 9$)$ or smaller (7 cases out of 9) than changes in the $\delta^{18} \mathrm{O}_{\mathrm{v}}$. Results are more ambiguous for d-excess $s_{\mathrm{s}}$, which is possibly due to the magnitude of the signal with respect to the larger analytical uncertainty associated with the water vapor measurements.

From this coevolution the following question arises: are the changes in the snow surface isotopes caused by changes in the water vapor isotopic composition, or are the water va- por isotope changes caused by changes in the snow surface isotopic composition?

\subsection{Possible causes for change in snow surface and water vapor isotopes}

We will only discuss changes in between precipitation events. If changes in the snow surface isotopes lead the changes in the water vapor isotopic composition, we need to explain why the isotopic composition of the snow surface is modified. Our first hypothesis is that the surface snow isotopic composition is affected by the isotopic composition of the firn below the top layer, itself reflecting the isotopic composition, at the time of campaign, of spring or winter snowfall. If this were the case, one would expect the surface snow isotopic composition to show a systematic decrease towards more depleted spring values. However, our observations depict 3 out of 9 cases where $\delta^{18} \mathrm{O}_{\mathrm{v}}$ is increasing, and 6 cases out of 9 when it is decreasing. A second hypothesis could be that, for a given $\delta^{18} \mathrm{O}_{\mathrm{s}}$, changes in nearsurface air temperature affect the isotopic composition of the water vapor formed at equilibrium with this snow. However, a $10^{\circ} \mathrm{C}$ warming only leads to a change of $\sim 2 \%$ in $\delta^{18} \mathrm{O}_{\mathrm{v}}$ under the assumption of isotopic equilibrium. This mechanism is therefore unable to account for the magnitude of $\delta^{18} \mathrm{O}_{\mathrm{s}}$ changes (Table 4). Finally, we cannot identify any mechanism that could explain why changes in $\delta^{18} \mathrm{O}_{\mathrm{s}}$ (alone) can lead to a larger change $\delta^{18} \mathrm{O}_{\mathrm{v}}$. We now investigate how mass fluxes between surface snow and atmosphere may explain this finding.

In order to guide our discussion of exchanges between the snow surface and the atmosphere, we use the mean daily vapor mass flux calculated by CROCUS (Fig. 5) to estimate the daily vapor mass flux from the snow surface to the atmosphere. The mass of the snow surface layer (top $0.5 \mathrm{~cm}$ ) 

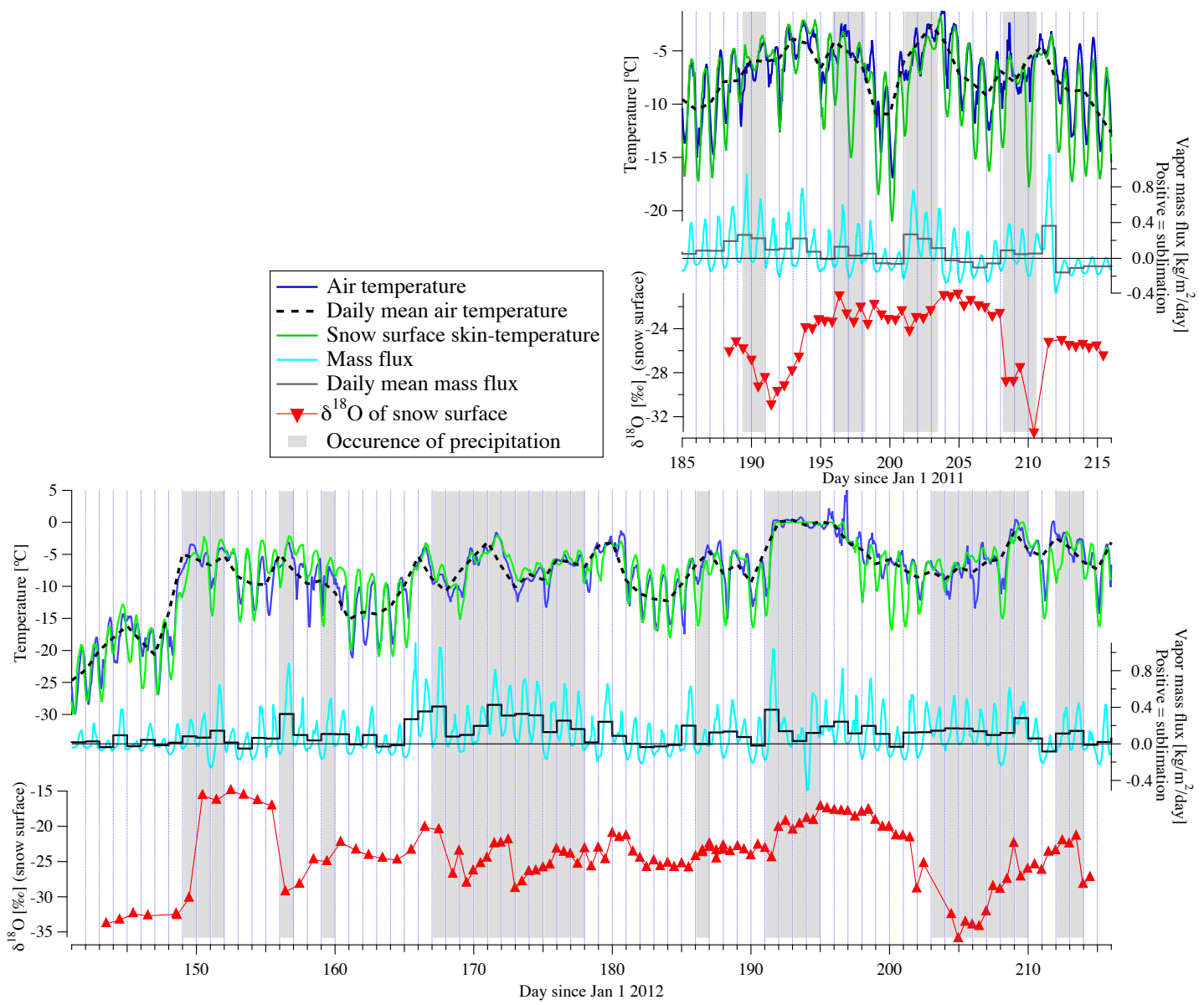

Fig. 5. Top and bottom panel show data from 2011 and 2012, respectively. The air temperature and snow surface skin temperature modeled by CROCUS are shown in blue and green, respectively (Daily mean air temperature shown in black). The estimated vapor mass flux from CROCUS with hourly resolution and daily mean values are shown in cyan and black, respectively. The variability in the surface snow $\delta^{18} \mathrm{O}_{\mathrm{S}}$ value is shown below.

is estimated to be $\sim 1.7 \mathrm{~kg} \mathrm{~m}^{-2}$, assuming a surface density of $340 \mathrm{~kg} \mathrm{~m}^{-3}$ (Steen-Larsen et al., 2011). For summer 2011 and 2012, the estimated flux varies between $\sim-0.15$ and $\sim 0.40 \mathrm{~kg} \mathrm{~m}^{-2} \mathrm{day}^{-1}$ (20\% of our surface samples), with a mean value of $\sim 0.1 \mathrm{~kg} \mathrm{~m}^{-2} \mathrm{day}^{-1}$ ( $6 \%$ of our surface samples). The largest values are identified during precipitation events. In between precipitation events, the average mass flux corresponds to $\sim 10 \%$ of the mass of the top layer each day.

Sublimation is normally assumed not to change the isotopic composition of the snow (Dansgaard, 1964; Town et al., 2008; Neumann and Waddington, 2004). However to test this hypothesis we will now investigate whether there is a simple fingerprint of sublimation in the changes of the isotopic composition of the snow surface. We note that CROCUS simulates net sublimation (positive mass flux) between days 191 and 196 of 2011, which corresponds to a negative trend of $\delta^{18} \mathrm{O}_{\mathrm{s}}$, and between days 152 and 156 (positive trend of $\delta^{18} \mathrm{O}_{\mathrm{s}}$ ), 160 and 166 (negative then positive trend of $\delta^{18} \mathrm{O}_{\mathrm{s}}$ ), and between 195 and 202 of 2012 (negative trend of $\delta^{18} \mathrm{O}_{\mathrm{s}}$ ).
We are therefore not able to identify any systematic relationship between sublimation and trends in $\delta^{18} \mathrm{O}_{\mathrm{s}}$.

Another hypothesis is that sampling of progressively older snow, as the snow surface is removed by sublimation, may cause the observed change in the snow surface isotopes. This hypothesis can be tested by comparing either earlier precipitation isotope data (for summer 2011) or by comparing earlier surface snow isotope data during precipitation events.

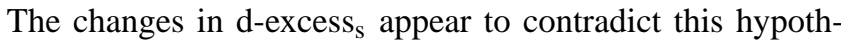

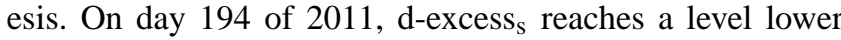
than observed during the previous precipitation event. Similarly, the drop in d-excess $\mathrm{s}_{\mathrm{s}}$ observed on day 165 of 2012 is lower than earlier values measured in the snow surface. The d-excess s $_{\mathrm{s}}$ maximum measured on day 202 of 2012 is higher than earlier snow measurements. During the same period (days 195 to 202, 2012), the observed d-excess increase $_{\mathrm{s}}$ is opposite to what would be expected based on the preceding precipitation event. We therefore do not find support for 
the hypothesis that sublimation causes sampling of the snow surface to be similar to playing a tape recorder in reverse.

We also hypothesize that surface snow isotopic composition reflects surface hoar formation. During NEEM field campaigns, such surface hoar formation was observed during clear-sky nights in response to condensation of water vapor in the air on to the cold snow surface. Similarly, deposition (negative mass flux from surface to atmosphere) is also simulated by CROCUS on days with a clear diurnal cycle. In these cases the simulated diurnal amount of sublimation is much larger than the simulated diurnal amount of condensation. It is therefore likely that the night frost would vanish throughout the day. The ice self-diffusion (diffusion inside the ice matrix) has a value of $\sim 5 \times 10^{-8} \mathrm{~m}^{2} \mathrm{yr}^{-1}$ at $-20^{\circ} \mathrm{C}$ (Whillans and Grootes, 1985) and the characteristic time for diffusion in a grain in the surface layer is about $10^{-2} \mathrm{yr}$ (Waddington et al., 2002). We therefore do not expect the snow surface to take up a significant isotopic signal from the surface hoar formed during the night. We do notice that, during clear-sky days, the diurnal cycle of sublimation/condensation is reflected in the water vapor diurnal cycles of both $\delta^{18} \mathrm{O}_{\mathrm{v}}$ and d-excess $\mathrm{v}_{\mathrm{v}}$ as also observed by Steen-Larsen et al. (2013).

At the day-to-day scale, our final hypothesis is that changes in snow surface isotopic composition are driven by synoptic changes in the atmospheric water vapor isotopic composition. First, the day-to-day variability of $\delta^{18} \mathrm{O}_{\mathrm{v}}$ is well captured by the LMDZiso atmospheric general circulation model, nudged to ECMWF operational analysis wind fields (Fig. 1). We therefore conclude that changes in the snow surface isotopes do not drive the variability in the water vapor isotopes, which instead is driven by changes in large-scale winds and moisture advection. The fact that changes in $\delta^{18} \mathrm{O}_{\mathrm{v}}$ in between precipitation events are always greater than or equal to the changes in $\delta^{18} \mathrm{O}_{\mathrm{s}}$ (Table 3) supports the hypothesis that the snow surface isotopic composition takes up part of the atmospheric water vapor signal.

So far, we do not have data available to constrain the nature of the process at play. For surface snow subjected to a temperature gradient of $0.5^{\circ} \mathrm{Ccm}^{-1}$, Pinzer et al. (2012) showed using X-ray-computed tomography that the characteristic residence time for a snow crystal to stay in place before being sublimated is $2-3$ days. This corresponds to a mass turnover time of $\sim 60 \%$ of total ice mass per day (Pinzer et al., 2012). Based on model outputs from CROCUS and our in situ temperature observations, such a temperature gradient occurs in the top $5 \mathrm{~cm}$ of the NEEM snowpack on clear-sky days. Larger temperature gradients in the top $1-2 \mathrm{~cm}$ of the snowpack cannot be excluded. We speculate that wind pumping (Clarke and Waddington, 1991; Neumann and Waddington, 2004) can cause a continuous replacement of the interstitial water vapor in the top snow layer. Due to the continuous recrystallization described by Pinzer et al. (2012), we hypothesize that this process leads to an imprint of changes in near-surface water vapor isotopic com- position into surface snow. Further investigations including controlled laboratory experiments and isotopic modeling are needed to understand how metamorphism processes can impact the $\delta^{18} \mathrm{O}$-temperature and d-excess- $-\delta^{18} \mathrm{O}$ relationships.

\section{Conclusions}

During the two warm summers of 2011 and 2012 at NEEM, continuous measurements of near-surface water vapor combined with isotopic measurements of snow samples collected every $12-24 \mathrm{~h}$ from the top $0.5 \mathrm{~cm}$ of the snow surface reveal parallel variations in between precipitation events, with larger variations in the vapor $\delta^{18} \mathrm{O}_{\mathrm{v}}$ than in the snow surface $\delta^{18} \mathrm{O}_{\mathrm{s}}$. We also report positive correlations between $\delta^{18} \mathrm{O}$ and temperature and negative correlations between d-excess and $\delta^{18} \mathrm{O}$ in the vapor data, but weaker correlations as well as different slopes in precipitation and surface snow data, a finding confirmed by results obtained from data sets acquired during earlier years at NEEM. We note a decoupling between vapor $\delta^{18} \mathrm{O}$ and temperature during the warmest days such as the summer 2012 heat wave. Changes in near-surface air temperature during the summer only account for a tiny fraction of the variability in precipitation and surface snow isotopic composition. This finding is consistent with investigations of shallow ice core data, which show much weaker relationships between Greenland summer $\delta^{18} \mathrm{O}$ and temperature records than during winter (Vinther et al., 2010). Simple isotopic calculations show that the hypothesis of equilibrium (Steen-Larsen et al., 2011) between near-surface vapor and surface snow cannot be ruled out when considering fractionation assuming liquid water or fractionation assuming ice when using newly estimated fractionation coefficient coefficients (Ellehoj et al., 2013).

The most surprising result from our work is the fact that surface snow and near-surface vapor evolve in tandem in between precipitation events, with similar or larger changes in vapor $\delta^{18} \mathrm{O}$ than in surface snow. The fact that an atmospheric general circulation model nudged to large-scale operational analysis wind fields is able to capture day-to-day variations in vapor isotopic composition shows that the near-surface water vapor isotopic composition is controlled by large-scale changes in air mass trajectories and distillation paths.

In an earlier work (Steen-Larsen et al., 2011), we had reported a diurnal cycle observed in near-surface air temperature, humidity and water vapor isotopic composition at the NEEM site during clear-sky days. The qualitative comparison with CROCUS mass flux calculations confirms that this cycle is very likely driven by diurnal cycle of condensation (hoar deposition at night and sublimation at day time). Further quantitative simulations would be required to implement water stable isotopes in a modeling framework including the surface snow and atmospheric boundary layer. For the NEEM site, 3 yr of continuous water vapor data (2010-2012) are available for the evaluation of such simulations. 
On day-to-day scales, no systematic relationship is observed between the CROCUS surface-atmosphere mass flux and our isotopic trend. We also show that sublimation does not make the surface reveal earlier precipitation and snow surface isotope values similar to a tape recorder played in reverse. We therefore suggest that day-to-day variations of surface snow isotopic composition in between precipitation events are caused by an uptake of the atmospheric water vapor isotopic signal driven by the continuous replacement of interstitial water vapor with atmospheric water vapor. This isotopic signal of the interstitial water vapor is then transferred into the surface snow due to snow metamorphism associated with a strong temperature gradient in the upper centimeters of the snow surface. Laboratory experiments conducted by injecting an isotopically known vapor into a snow disk of known isotopic composition and different temperature gradients are needed in order to quantify the magnitude and rates of changes of the isotopic processes occurring during controlled snow metamorphism. Such laboratory experiments would also allow for validating the implementation of water stable isotopes in snow models such as CROCUS. Similar monitoring frameworks in different places could investigate the validity of our findings for other sites. If our interpretation of the observed signals is correct, changes in surface snow isotopic composition are expected to be significant (i) if large day-to-day surface changes in water vapor occur in between precipitation events, (ii) wind pumping is efficient and (iii) snow metamorphism is enhanced by large temperature gradients in the upper first centimeters of the snow. Due to prolonged periods of time between precipitation events, central East Antarctica would be an excellent site for a case study, albeit with the challenge to accurately measure the isotopic composition of water vapor at very low concentrations, even in summer, when metamorphism is expected to be larger.

Our hypothesis that the surface snow isotopic composition is affected by isotopic exchanges with the atmospheric water vapor in between precipitation events also has implications for the interpretation of ice core records. Indeed, classically, ice core stable isotope records are interpreted as reflecting precipitation-weighted signals, and compared to observations (e.g., station data, atmospheric reanalysis) and atmospheric model results for precipitation (using $\delta^{18} \mathrm{O}$ precipitation data, or precipitation-weighted temperature), ignoring such snow-vapor exchanges. Recording a surface climate signal even when no precipitation is deposited suggests a more continuous archiving process than previously thought, but makes the comparison with atmospheric simulations more challenging. It has long been known that processes in the surface snow attenuate the signal associated with each precipitation event. Mathematical calculations of so-called isotopic diffusion require being reconciled with the physical understanding of the processes at play. Our findings also challenge the use of purely statistical back-diffusion calculations in order to restore the full magnitude of seasonal variations, a method classically applied for identifying seasonal cycles in damped isotopic signals.

\section{Supplementary material related to this article is available online at http://www.clim-past.net/10/377/2014/ cp-10-377-2014-supplement.pdf.}

Acknowledgements. This paper is dedicated to the memory of our friend and mentor Sigfús J. Johnsen (1940-2013) for being an unlimited source of inspiration and encouragement. NEEM is directed and organized by the Centre for Ice and Climate at the Niels Bohr Institute and US NSF, Office of Polar Programs. It is supported by funding agencies and institutions in Belgium (FNRS-CFB and FWO), Canada (GSC), China (CAS), Denmark (FIST), France (IPEV, INSU/CNRS and ANR VMC NEEM), Germany (AWI), Iceland (RannIs), Japan (NIPR), Korea (KOPRI), the Netherlands (NWO/ALW), Sweden (VR), Switzerland (SNF), the UK (NERC) and the USA (US NSF, Office of Polar Programs). The numerical simulations with LMDZiso were performed on the NEC-SX8 of the IDRIS/CNRS computing center. The work was supported by the Danish Council for Independent Research - Natural Sciences grant number 09-072689 and 10-092850, by the French Agence Nationale de la Recherche (grants VMC NEEM and CEPS GREENLAND), and by the AXA Research Fund. We also acknowledge the MODIS mission scientists and associated NASA personnel for the production of the data used in this research effort.

The authors thank the editor and two anonymous reviewers for valuable suggestions during the review process, which improved the final version of this paper.

Edited by: E. Wolff

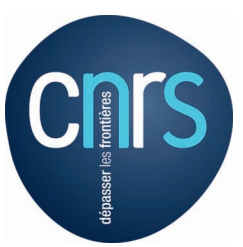

The publication of this article is financed by CNRS-INSU.

\section{References}

Barkan, E. and Luz, B.: High precision measurements of $\mathrm{O}_{17} / \mathrm{O}_{16}$ and $\mathrm{O}_{18} / \mathrm{O}_{16}$ ratios in $\mathrm{H}_{2} \mathrm{O}$, Rapid Commun. Mass Sp., 19, 3737-3742, doi:10.1002/rcm.2250, 2005.

Brun, E., Six, D., Picard, G., Vionnet, V., Arnaud, L., Bazile, E., Boone, A., Bouchard, A., lie, Genthon, C., Guidard, V., Le Moigne, P., Rabier, F., and Seity, Y.: Snow/atmosphere coupled simulation at dome c, antarctica, J. Glaciol., 57, 721-736, 2011.

Brun, E., Vionnet, V., Boone, A., Decharme, B., Peings, Y., Valette, R. M., Karbou, F., and Morin, S.: Simulation of northern eurasian local snow depth, mass, and density using a detailed snowpack model and meteorological reanalyses, J. Hydrometeorol., 14, 203-219, doi:10.1175/jhm-d-12-012.1, 2013.

Clarke, G. K. C. and Waddington, E. D.: A three-dimensional theory of wind pumping, J. Glaciol., 37, 89-96, 1991. 
Cuffey, K. M. and Steig, E. J.: Isotopic diffusion in polar firn: implications for interpretation of seasonal climate parameters in icecore records, with emphasis on central greenland, J. Glaciol., 44, 273-284, 1998

Dahl-Jensen, D., Mosegaard, K., Gundestrup, N., Clow, G. D., Johnsen, S. J., Hansen, A. W., and Balling, N.: Past temperatures directly from the greenland ice sheet, Science, 282, 268271, 1998

Dansgaard, W.: Stable isotopes in precipitation, Tellus, 16, 436468, 1964.

Dee, D. P., Uppala, S. M., Simmons, A. J., Berrisford, P., Poli, P., Kobayashi, S., Andrae, U., Balmaseda, M. A., Balsamo, G., Bauer, P., Bechtold, P., Beljaars, A. C. M., van de Berg, L., Bidlot, J., Bormann, N., Delsol, C., Dragani, R., Fuentes, M., Geer, A. J., Haimberger, L., Healy, S. B., Hersbach, H., Hólm, E. V., Isaksen, L., Kållberg, P., Köhler, M., Matricardi, M., McNally, A. P., Monge-Sanz, B. M., Morcrette, J. J., Park, B. K., Peubey, C., de Rosnay, P., Tavolato, C., Thépaut, J. N., and Vitart, F.: The era-interim reanalysis: configuration and performance of the data assimilation system, Q. J. Roy. Meteor. Soc., 137, 553-597, doi:10.1002/qj.828, 2011.

Ellehoj, M. D., Steen-Larsen, H. C., Johnsen, S. J., and Madsen, M. B.: Ice-vapor equilibrium fractionation factor of hydrogen and oxygen isotopes: experimental investigations and implications for stable water isotope studies, Rapid Commun. Mass Sp., 27, 2149-2158, doi:10.1002/rcm.6668, 2013.

Fisher, D. A. and Koerner, R. M.: The effects of wind on $\mathrm{d}\left({ }^{18} \mathrm{O}\right)$ and accumulation give an inferred record of seasonal d amplitude from the agassiz ice cap, ellesmere island, Canada, Ann. Glaciol., 10, 34-37, 1988.

Fisher, D. A. and Koerner, R. M.: Signal and noise in four ice-core records from the agassiz ice cap, ellesmere island, canada: Details of the last millennium for stable isotopes, melt and solid conductivity, The Holocene, 4, 113-120, 1994.

Guillevic, M., Bazin, L., Landais, A., Kindler, P., Orsi, A., MassonDelmotte, V., Blunier, T., Buchardt, S. L., Capron, E., Leuenberger, M., Martinerie, P., Prié, F., and Vinther, B. M.: Spatial gradients of temperature, accumulation and $\delta^{18} \mathrm{O}$-ice in Greenland over a series of Dansgaard-Oeschger events, Clim. Past, 9, 1029-1051, doi:10.5194/cp-9-1029-2013, 2013.

Hourdin, F., Musat, I., Bony, S., Braconnot, P., Codron, F., Dufresne, J. L., Fairhead, L., Filiberti, M. A., Friedlingstein, P., Grandpeix, J. Y., Krinner, G., Levan, P., Li, Z. X., and Lott, F.: The lmdz4 general circulation model: Climate performance and sensitivity to parametrized physics with emphasis on tropical convection, Clim. Dynam., 27, 787-813, doi:10.1007/s00382006-0158-0, 2006.

Johnsen, S. J.: Stable isotope homogenization of polar firn and ice, in: Proc. of Symp. on isotopes and impurities in snow and ice, i.U.G.G. Xvi, general assembly, grenoble aug. September 1975, Iahs-aish publ. 118, Washington DC, 210-219, 1977.

Johnsen, S. J., Dansgaard, W., and White, J. W. C.: The origin of arctic precipitation under present and glacial conditions, Tellus B, 41, 452-468, 1989.

Johnsen, S. J., Clausen, H. B., Cuffey, K. M., Hoffmann, G., Schwander, J., and Creyts, T.: Diffusion of stable isotopes in polar firn and ice: the isotope effect in firn diffusion, in: Physics of Ice Core Records, edited by: Hondoh, T., Hokkaido University Press, Sapporo, 121-140, 2000.
Johnsen, S. J., Dahl-Jensen, D., Gundestrup, N., Steffensen, J. P., Clausen, H. B., Miller, H., Masson-Delmotte, V., Sveinbjörnsdottir, A. E., and White, J.: Oxygen isotope and palaeotemperature records from six greenland ice-core stations: Camp century, dye-3, grip, gisp2, renland and northgrip, J. Quaternary Sci., 16 , 299-307, 2001.

Jouzel, J. and Merlivat, L.: Deuterium and oxygen 18 in precipitation: modeling of the isotopic effects during snow formation, J. Geophys. Res., 89, 11749-11757, 1984.

Jouzel, J., Alley, R. B., Cuffey, K. M., Dansgaard, W., Grootes, P., Hoffmann, G., Johnsen, S. J., Koster, R. D., Peel, D., Shuman, C. A., Stievenard, M., Stuiver, M., and White, J.: Validity of the temperature reconstruction from water isotopes in ice cores, J. Geophys. Res., 102, 26471-26487, 1997.

Kindler, P., Guillevic, M., Baumgartner, M., Schwander, J., Landais, A., and Leuenberger, M.: NGRIP temperature reconstruction from 10 to $120 \mathrm{kyr}$ b2k, Clim. Past Discuss., 9, 40994143, doi:10.5194/cpd-9-4099-2013, 2013.

Krinner, G., Genthon, C., and Jouzel, J.: Gcm analysis of local influences on ice core d signals, Geophys. Res. Lett., 24, 2825-2828, 1997.

Landais, A., Caillon, N., Severinghaus, J., Barnola, J.-M., Goujon, C. L., Jouzel, J., and Masson-Delmotte, V. R.: Isotopic measurements of air trapped in ice to quantify temperature changes, C. R. Geosci., 336, 963-970, doi:10.1016/j.crte.2004.03.013, 2004.

Landais, A., Steen-Larsen, H. C., Guillevic, M., MassonDelmotte, V., Vinther, B., and Winkler, R.: Triple isotopic composition of oxygen in surface snow and water vapor at neem (greenland), Geochim. Cosmochim. Ac., 77, 304-316, 2012.

Majoube, M.: Fractionation factor of ${ }^{18} \mathrm{O}$ between water vapour and ice, Nature, 226, p. 1242, 1970.

Majoube, M.: Fractionnement en oxygène 18 et en deutérium entre l'eau et sa vapeur, J. Climate Phys., 68, 1423-1436, 1971.

Masson-Delmotte, V., Jouzel, J., Landais, A., Stievenard, M., Johnsen, S. J., White, J. W. C., Werner, M., Sveinbjornsdottir, A., and Fuhrer, K.: Grip deuterium excess reveals rapid and orbitalscale changes in greenland moisture origin, Science, 309, 118 121, 2005a.

Masson-Delmotte, V., Landais, A., Stievenard, M., Cattani, O., Falourd, S., Jouzel, J., Johnsen, S. J., Dahl-Jensen, D., Sveinbjornsdottir, A., White, J. W. C., Popp, T., and Fisher, H.: Holocene climatic changes in greenland: Different deuterium excess signals at greenland ice core project (grip) and northgrip, J. Geophys. Res., 110, D14102, doi:10.1029/2004JD005575, 2005b.

Merlivat, L. and Jouzel, J.: Global climatic interpretation of the deuterium-oxygen 18 relationship for precipitation, J. Geophys. Res., 84, 5029-5033, 1979.

Merlivat, L. and Nief, G.: Fractionnement isotopique lors des changements d'état solide-vapeur et liquide-vapeur de l'eau à des températues inférieures à $0^{\circ} \mathrm{C}$, Tellus, 1, 122-127, 1967.

NEEM Community members: Eemian interglacial reconstructed from a greenland folded ice core, Nature, 493, 489-494, 2013.

Neumann, T. A. and Waddington, E. D.: Effects of firn ventilation on isotopic exchange, J. Glaciol., 50, 183-194, 2004.

Newell, R. E. and Zhu, Y.: Tropospheric River: A one-year record and a possible application to ice core data, Geophys. Res. Lett., 21, 113-116, doi:10.1029/93GL03113, 1994 
Nghiem, S. V., Hall, D. K., Mote, T. L., Tedesco, M., Albert, M. R., Keegan, K., Shuman, C. A., DiGirolamo, N. E., and Neumann, G.: The extreme melt across the greenland ice sheet in 2012, Geophys. Res. Lett., 39, L20502, doi:10.1029/2012g1053611, 2012.

Ortega, P., Swingedouw, D., Masson-Delmotte, V., Risi, C., Vinther, B., Yiou, P., Vautard, R., and Yoshimura, K.: Characterizing atmospheric circulation signals in greenland ice cores: insights from weather regime approach, Clim. Dynam., accepted, doi:10.1007/s00382-014-2074-z, 2014.

Persson, A., Langen, P. L., Ditlevsen, P., and Vinther, B. M.: The influence of precipitation weighting on interannual variability of stable water isotopes in greenland, J. Geophys. Res.-Atmos., 116, D20120, doi:10.1029/2010jd015517, 2011.

Pinzer, B. R., Schneebeli, M., and Kaempfer, T. U.: Vapor flux and recrystallization during dry snow metamorphism under a steady temperature gradient as observed by time-lapse microtomography, The Cryosphere, 6, 1141-1155, doi:10.5194/tc-61141-2012, 2012.

Rae, J. G. L., Alalgeirsdottir, G., Edwards, T. L., Fettweis, X., Gregory, J. M., Hewitt, H. T., Lowe, J. A., LucasPicher, P., Mottram, R. H., Payne, A. J., Ridley, J. K., Shannon, S. R., van de Berg, W. J., van de Wal, R. S. W., and van den Broeke, M. R.: Greenland ice sheet surface mass balance: evaluating simulations and making projections with regional climate models, The Cryosphere, 6, 1275-1294, doi:10.5194/tc-6-1275-2012, 2012.

Risi, C., Bony, S., Vimeux, F., and Jouzel, J.: Water stable isotopes in the 1mdz4 general circulation model: model evaluation for present day and past climates and applications to climatic interpretations of tropical isotopic records, J. Geophys. Res., 115, D12118, doi:10.1029/2009JD013255, 2010.

Risi, C., Noone, D., Frankenberg, C., and Worden, J.: Role of continental recycling in intraseasonal variations of continental moisture as deduced from model simulations and water vapor isotopic measurements, Water Resour. Res., 49, 4136-4156, doi:10.1002/wrcr.20312, 2013.

Severinghaus, J. P. and Brook, E. J.: Abrupt climate change at the end of the last glacial period inferred from trapped air in polar ice, Science, 286, 930-943, 1999.

Sjolte, J., Hoffmann, G., Johnsen, S. J., Vinther, B. M., Masson-Delmotte, V., and Sturm, C.: Modeling the water isotopes in greenland precipitation 1959-2001 with the meso-scale model remo-iso, J. Geophys. Res., 116, D18105, doi:10.1029/2010jd015287, 2011.

Steen-Larsen, H. C., Masson-Delmotte, V., Sjolte, J., Johnsen, S. J., Vinther, B. M., Breon, F. M., Clausen, H. B., Dahl-Jensen, D., Falourd, S., Fettweis, X., Gallee, H., Jouzel, J., Kageyama, M., Lerche, H., Minster, B., Picard, G., Punge, H. J., Risi, C., Salas, D., Schwander, J., Steffen, K., Sveinbjornsdottir, A. E., Svensson, A., and White, J.: Understanding the climatic signal in the water stable isotope records from the neem shallow firn/ice cores in northwest greenland, J. Geophys. Res.-Atmos., 116, D06108, doi:10.1029/2010jd014311, 2011.
Steen-Larsen, H. C., Johnsen, S. J., Masson-Delmotte, V., Stenni, B., Risi, C., Sodemann, H., Balslev-Clausen, D., Blunier, T., Dahl-Jensen, D., Ellehøj, M. D., Falourd, S., Grindsted, A., Gkinis, V., Jouzel, J., Popp, T., Sheldon, S., Simonsen, S. B., Sjolte, J., Steffensen, J. P., Sperlich, P., Sveinbjörnsdóttir, A. E., Vinther, B. M., and White, J. W. C.: Continuous monitoring of summer surface water vapor isotopic composition above the Greenland Ice Sheet, Atmos. Chem. Phys., 13, 48154828, doi:10.5194/acp-13-4815-2013, 2013.

Steffen, K. and Box, J.: Surface climatology of the greenland ice sheet: Greenland climate network 1995-1999, J. Geophys. Res., 106, 33951-33964, 2001.

Steffen, K., Box, J. E., and Abdalati, W.: Greenland climate network: Gc-net, CRREL 96-27 Special Report on glaciers, Ice Sheets and Volcanoes, trib. to M. Meier, 98-103, 1996.

Steffensen, J. P., Andersen, K. K., Bigler, M., Clausen, H. B., Dahl-Jensen, D., Fischer, H., Goto-Azuma, K., Hansson, M., Johnsen, S. J., Jouzel, J., Masson-Delmotte, V., Popp, T., Rasmussen, S. O., Rothlisberger, R., Ruth, U., Stauffer, B., SiggaardAndersen, M. L., Sveinbjornsdottir, A. E., Svensson, A., and White, J. W. C.: High-resolution greenland ice core data show abrupt climate change happens in few years, Science, 321, 680 684, doi:10.1126/science.1157707, 2008.

Town, M. S., Warren, S. G., Walden, V. P., and Waddington, E. D.: Effect of atmospheric water vapor on modification of stable isotopes in near-surface snow on ice sheets, J. Geophys. Res.Atmos., 113, D24303, doi:10.1029/2008jd009852, 2008.

Vinther, B. M., Jones, P. D., Briffa, K. R., Clausen, H. B., Andersen, K. K., Dahl-Jensen, D., and Johnsen, S. J.: Climatic signals in multiple highly resolved stable isotope records from greenland, Quaternary Sci. Rev., 29, 522-538, 2010.

Vionnet, V., Brun, E., Morin, S., Boone, A., Faroux, S., Le Moigne, P., Martin, E., and Willemet, J.-M.: The detailed snowpack scheme Crocus and its implementation in SURFEX v7.2, Geosci. Model Dev., 5, 773-791, doi:10.5194/gmd-5-7732012, 2012.

Waddington, E. D., Steig, E. J., and Newmann, T. A.: Using characteristic times to assess whether stable isotopes in polar snow can be reversibly deposited, Ann. Glaciol., 35, 118-124, 2002.

Wan: Collection-5 modis land surface temperature products user's guide, available at: www.icess.ucsb.edu/modis/LstUsrGuide/ MODIS_LST_products_Users_guide_C5.pdf (last access: 1 October 2013), 2009.

Werner, M., Heimann, M., and Hoffmann, G.: Isotopic composition and origin of polar precipitation in present and glacial climate simulations, Tellus B, 53, 53-71, 2001.

Whillans, I. M. and Grootes, P. M.: Isotopic diffusion in cold snow and firn, J. Geophys. Res., 90, 3910-3918, 1985.

White, J. W. C., Barlow, L. K., Fisher, D., Grootes, P. M., Jouzel, J., Johnsen, S. J., Stuiver, M., and Clausen, H.: The climate signal in the stable isotopes from summit, greenland: Results of comparisons with modern climate observations., J. Geophys. Res., 102, 26425-26439, 1997.

Yoshimura, K., Kanamitsu, M., Noone, D., and Oki, T.: Historical isotope simulation using reanalysis atmospheric data, J. Geophys. Res.-Atmos., 113, D19108, doi:10.1029/2008jd010074, 2008. 